Prepared in cooperation with the Arkansas Department of Environmental Quality, Southwestern Energy, the Arkansas Natural Resources Commission, and the Arkansas Game and Fish Commission

\title{
Dry Season Mean Monthly Flow and Harmonic Mean Flow Regression Equations for Selected Ungaged Basins in Arkansas
}

Scientific Investigations Report 2015-5031

Version 1.1, July 2015 



\section{Dry Season Mean Monthly Flow and Harmonic Mean Flow Regression Equations for Selected Ungaged Basins in Arkansas}

By Brian K. Breaker

Prepared in cooperation with the Arkansas Department of Environmental Quality, Southwestern Energy, the Arkansas Natural Resources Commission, and the Arkansas Game and Fish Commission

Scientific Investigations Report 2015-5031

Version 1.1, July 2015 


\title{
U.S. Department of the Interior SALLY JEWELL, Secretary
}

\section{U.S. Geological Survey Suzette M. Kimball, Acting Director}

\author{
U.S. Geological Survey, Reston, Virginia: 2015 \\ First release: 2015 \\ Revised: July 2015 (ver 1.1)
}

\begin{abstract}
For more information on the USGS - the Federal source for science about the Earth, its natural and living resources, natural hazards, and the environment—visit http://www.usgs.gov or call 1-888-ASK-USGS.

For an overview of USGS information products, including maps, imagery, and publications, visit http://www.usgs.gov/pubprod/.
\end{abstract}

\footnotetext{
Any use of trade, firm, or product names is for descriptive purposes only and does not imply endorsement by the U.S. Government.

Although this information product, for the most part, is in the public domain, it also may contain copyrighted materials as noted in the text. Permission to reproduce copyrighted items must be secured from the copyright owner.

Suggested citation:

Breaker, B.K., 2015, Dry season mean monthly flow and harmonic mean flow regression equations for selected ungaged basins in Arkansas (ver. 1.1, July 2015): U.S. Geological Survey Scientific Investigations Report 2015-5031, 25 p., http://dx.doi.org/10.3133/sir20155031.

ISSN 2328-0328 (online)
} 


\section{Contents}

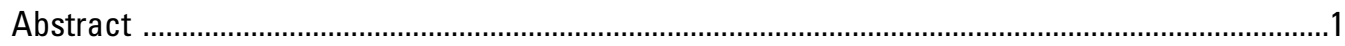

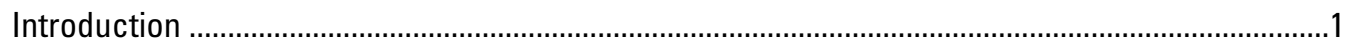

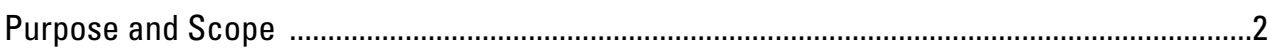

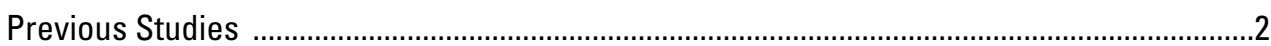

Methods of Analysis for Data from U.S. Geological Survey Continuous-Record Streamflow

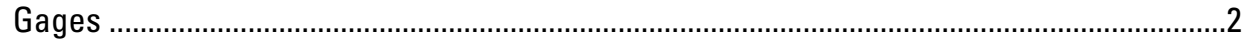

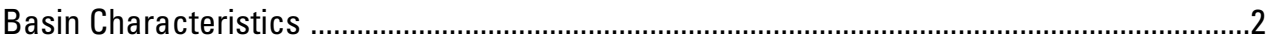

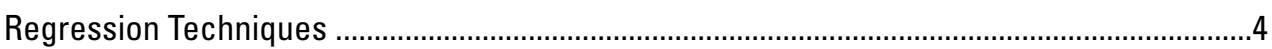

Dry Season Mean Monthly Flow Data .................................................................................

Harmonic Mean Flow Data ...........................................................................................

Regionalization of Harmonic Mean Flow Data .................................................................5

Dry Season Mean Monthly Flow and Harmonic Mean Flow Regression Equations .........................7

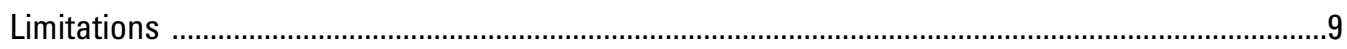

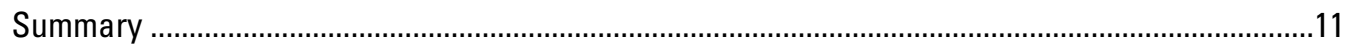

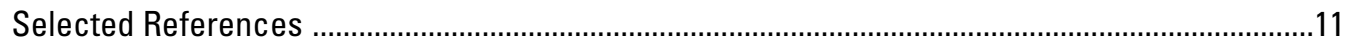

Appendix 1. U.S. Geological Survey Streamflow Gages Used for Regression Analysis for Dry Season Mean Monthly Flow and Harmonic Mean Flow .............................15

Appendix 2. Definitions of Basin Characteristics Evaluated as Response Variables for Inclusion in the Regression Analysis .....................................................................19

Appendix 3. Dry Season Mean Monthly Flow, Harmonic Mean Flow, and Explanatory Variable Values for Final Regression Equations ...................................................21

\section{Figures}

1. Map showing U.S. Geological Survey streamflow gages used for dry season mean monthly flow and harmonic mean flow regressions ..............................................

2. Map showing physiographic sections of Arkansas .........................................................

\section{Tables}

1. Range of basin characteristic values used to develop dry season mean monthly flow and harmonic mean flow regression equations for unregulated streams in Arkansas

2. Regression equations and ancillary regression diagnostics for dry season mean monthly flow estimation in Arkansas

3. Regression equations and ancillary regression diagnostics for harmonic mean flow estimation in two regions identified in Arkansas

4. Values needed to determine the 90-percent prediction intervals for estimates obtained from regression equations using covariance matrices in Arkansas 


\section{Conversion Factors}

Inch/Pound to International System of Units

\begin{tabular}{lcl}
\hline \multicolumn{1}{c}{ Multiply } & By & \multicolumn{1}{c}{ To obtain } \\
\hline inch (in.) & Length & \\
foot (ft) & 2.54 & centimeter $(\mathrm{cm})$ \\
mile (mi) & 0.3048 & meter $(\mathrm{m})$ \\
\hline & 1.609 & kilometer $(\mathrm{km})$ \\
\hline square mile $\left(\mathrm{mi}^{2}\right)$ & Area & hectare $(\mathrm{ha})$ \\
square mile $\left(\mathrm{mi}^{2}\right)$ & 259.0 & square kilometer $\left(\mathrm{km}^{2}\right)$ \\
\hline & 2.590 & \\
\hline cubic foot per second $\left(\mathrm{ft}^{3} / \mathrm{s}\right)$ & Flow rate & cubic meter per second $\left(\mathrm{m}^{3} / \mathrm{s}\right)$ \\
million gallons per day $(\mathrm{Mgal} / \mathrm{d})$ & 0.02832 & cubic meters per second $\left(\mathrm{m}^{3} / \mathrm{s}\right)$ \\
\hline & 0.04381 & meter per kilometer $(\mathrm{m} / \mathrm{km})$ \\
\hline foot per mile $(\mathrm{ft} / \mathrm{mi})$ & Hydraulic gradient &
\end{tabular}

\section{Datum}

Vertical coordinate information is referenced to the North American Vertical Datum of 1988 (NAVD 88).

Horizontal coordinate information is referenced to the North American Datum of 1983 (NAD 83).

\section{Abbreviations}

$\begin{array}{ll}\text { ADEO } & \text { Arkansas Department of Environmental Quality } \\ \text { EPA } & \text { U.S. Environmental Protection Agency } \\ \text { GIS } & \text { Geographic Information System } \\ \text { MLR } & \text { multiple-linear-regression } \\ \text { NPDES } & \text { National Pollutant Discharge Elimination System } \\ \text { NRMSE } & \text { normalized root mean square error } \\ \text { NWIS } & \text { National Water Information System } \\ \text { OLS } & \text { ordinary-least-squares } \\ \text { PBIAS } & \text { percent bias } \\ \text { QAH } & \text { harmonic mean flow } \\ \text { R }^{2} & \text { coefficient of determination } \\ \text { RSE } & \text { residual standard error } \\ \text { USGS } & \text { U.S. Geological Survey } \\ \text { WLS } & \text { weighted-least-squares }\end{array}$




\title{
Dry Season Mean Monthly Flow and Harmonic Mean Flow Regression Equations for Selected Ungaged Basins in Arkansas
}

\author{
By Brian K. Breaker
}

\section{Abstract}

The U.S. Geological Survey, in cooperation with the Arkansas Department of Environmental Quality, Southwestern Energy, the Arkansas Natural Resources Commission, and the Arkansas Game and Fish Commission, developed regression equations for estimation of dry season mean monthly flows and harmonic mean flows that are representative of natural streamflow conditions at selected ungaged basins in Arkansas. Observed values of dry season mean monthly flow and harmonic mean flow computed from daily-mean flow data were used with basin characteristics to identify significant explanatory variables for multiple-linear-regression equations to estimate predicted values of dry season mean monthly flow and harmonic mean flow. Five dry season mean monthly flow regression equations and two harmonic mean flow regression equations were developed using dry season mean monthly flows and harmonic mean flows established for 91 and 93 U.S. Geological Survey continuous-record streamflowgaging stations, respectively. The dry season in Arkansas is defined as the months of July through November for this study. For harmonic mean flow calculations and regression equations, the study area is composed of the SpringfieldSalem Plateaus (Arkansas and Missouri), Boston Mountains, Arkansas Valley, Ouachita Mountains (Arkansas and Oklahoma), and West Gulf Coastal Plain (Arkansas) physiographic sections. All continuous-record streamflow-gaging stations used to compute dry season mean monthly flows were located within Arkansas.

Equations for two regions were found to be statistically significant for developing regression equations for estimating harmonic mean flows at ungaged basins; thus, equations are applicable only to streams in those respective regions in Arkansas. Regression equations for dry season mean monthly flows are applicable only to streams located throughout Arkansas. All regression equations are applicable only to unaltered streams where flows were not significantly affected by regulation, diversion, or urbanization. The median number of years used for dry season mean monthly flow calculation was 43 , and the median number of years used for harmonic mean flow calculations was 34 for region 1 and 43 for region 2 .

\section{Introduction}

Water use in the State of Arkansas was estimated to be about 11,500 million gallons per day in 2010 (A.L. Pugh and Terrance W. Holland, U.S. Geological Survey, written commun., 2014). Groundwater and surface-water sources comprised 69 percent and 31 percent, respectively, of total water use. Total water use increased in Arkansas by 435 percent between 1965 and 2010 (A.L. Pugh and Terrance W. Holland, U.S. Geological Survey, written commun., 2014). As population and agriculture in Arkansas continue to increase, more stress is placed on streams in the State. The Arkansas Department of Environmental Quality (ADEQ) protects and regulates water resources of Arkansas through various programs (http://www.adeq.state.ar.us/Default.htm) involving permitting. Through issuance of National Pollutant Discharge Elimination System (NPDES) permits, the ADEQ is responsible for ensuring waters of the State of Arkansas are suitable for sustaining diverse biological communities and do not simultaneously pose threats to human health. The NPDES permits are required for industrial, municipal, or other facilities that discharge treated wastewater directly to surface waters. The U.S. Environmental Protection Agency (EPA) recommends that the long-term harmonic mean flow be used for assessing potential human health effects because it provides a more conservative estimate than the arithmetic mean flow. The harmonic mean flow is determined by taking the reciprocal of the mean value of the reciprocal of individual values.

The U.S. Geological Survey (USGS), in cooperation with the ADEQ, Southwestern Energy, the Arkansas Natural Resources Commission, and the Arkansas Game and Fish Commission, developed regional regression equations for estimation of dry season mean monthly flows and harmonic mean flows that are representative of natural streamflow conditions, defined as streamflows that are not affected by regulation, diversion, or urbanization (referred to hereinafter as unaltered) at ungaged basins in Arkansas. A continuousrecord streamflow-gaging station (referred to hereinafter as a streamflow gage) is a location on a stream where gage height is recorded continuously and for which daily-mean streamflow is computed (Funkhouser and others, 2008). 
Dry season mean monthly flows and harmonic mean flows are routinely needed for ungaged streams for water-quality regulation, stream-related structural design, wastewater management, and stream-hazard identification. These two streamflow statistics, in particular, are useful for setting criteria for wastewater-treatment plant effluent and allowable pollutant loads to meet water-quality standards for human health criteria, irrigation, recreation, and wildlife conservation. For the estimation of these two statistics at ungaged streams, regional regression equations were developed using statistical relations that exist between streamflow data collected at streamflow gages and geologic, climatic, physical, and statistical variables for watersheds that contribute flow to a streamflow gage (Eash and Barnes, 2012).

\section{Purpose and Scope}

The purpose of this report is to present regression equations for estimation of dry season mean monthly flows and harmonic mean flows (QAH) at ungaged basins in Arkansas. Dry season mean monthly flows and QAH computed from USGS streamflow gages are also presented. Equations developed during this study also are intended for delivery in the USGS StreamStats program (U.S. Geological Survey, 2012a,b). The StreamStats program allows users to select a point on a stream in an interactive map and then automatically delineates the watershed for that point and computes selected statistics for the watershed (Eash and Barnes, 2012). The StreamStats program will provide users the ability to estimate dry season mean monthly flow, QAH, and associated 90 percent prediction intervals for ungaged streams in Arkansas.

\section{Previous Studies}

Six studies have been conducted for estimation of lowflow characteristics in Arkansas beginning with Hines (1965). The most recent study by Funkhouser and others (2008) used data collected through the 2005 water year, defined as the period from October 1 of a given year to September 30 of the following year designated by the calendar year in which it ends. Previous reports for low-flow statistics in Arkansas have focused primarily on development of regional regression equations for low-flow frequencies, such as the 7-day, 2-year low flow $\left(\mathrm{Q}_{7,2}\right)$ and the 7-day, 10-year low flow $\left(\mathrm{Q}_{7,10}\right)$. No previous studies in Arkansas have developed regional regression equations to estimate dry season mean monthly flow or QAH.

\section{Methods of Analysis for Data from U.S. Geological Survey Continuous-Record Streamflow Gages}

Data used for this report are from 113 streamflow gages in Arkansas, Oklahoma, and Missouri (fig. 1); however, streamflow gages from neighboring States were used only for QAH because explanatory variables used in regression equations for dry season mean monthly flow were spatially limited to within Arkansas. Streamflow gages from neighboring States were used to improve the representativeness of QAH and basin characteristics found in the Arkansas border areas and to provide better estimates of the error of the regression equations for ungaged sites near the Arkansas border. Streamflow gages located on unaltered streams (fig. 1; app. 1) with a minimum of 15 water years of daily-mean flows were initially selected for evaluation in the study. However, some gages with 12 water years of daily-mean flow data were added to enhance the spatial distribution of streamflow gages used to develop regression equations. Daily-mean flow data collected through the 2013 water year were retrieved for the 113 streamflow gages from the USGS National Water Information System (NWIS) database (U.S. Geological Survey, 2001).

\section{Basin Characteristics}

For this study, 47 basin characteristics (app. 2) were evaluated as potential explanatory variables for use in regression equations for estimating dry season mean monthly flow and QAH. The geographic information system (GIS) derived characteristics were selected to represent the varying geologic, climatic, physical, and statistical properties of the watersheds for the 113 streamflow gages. 


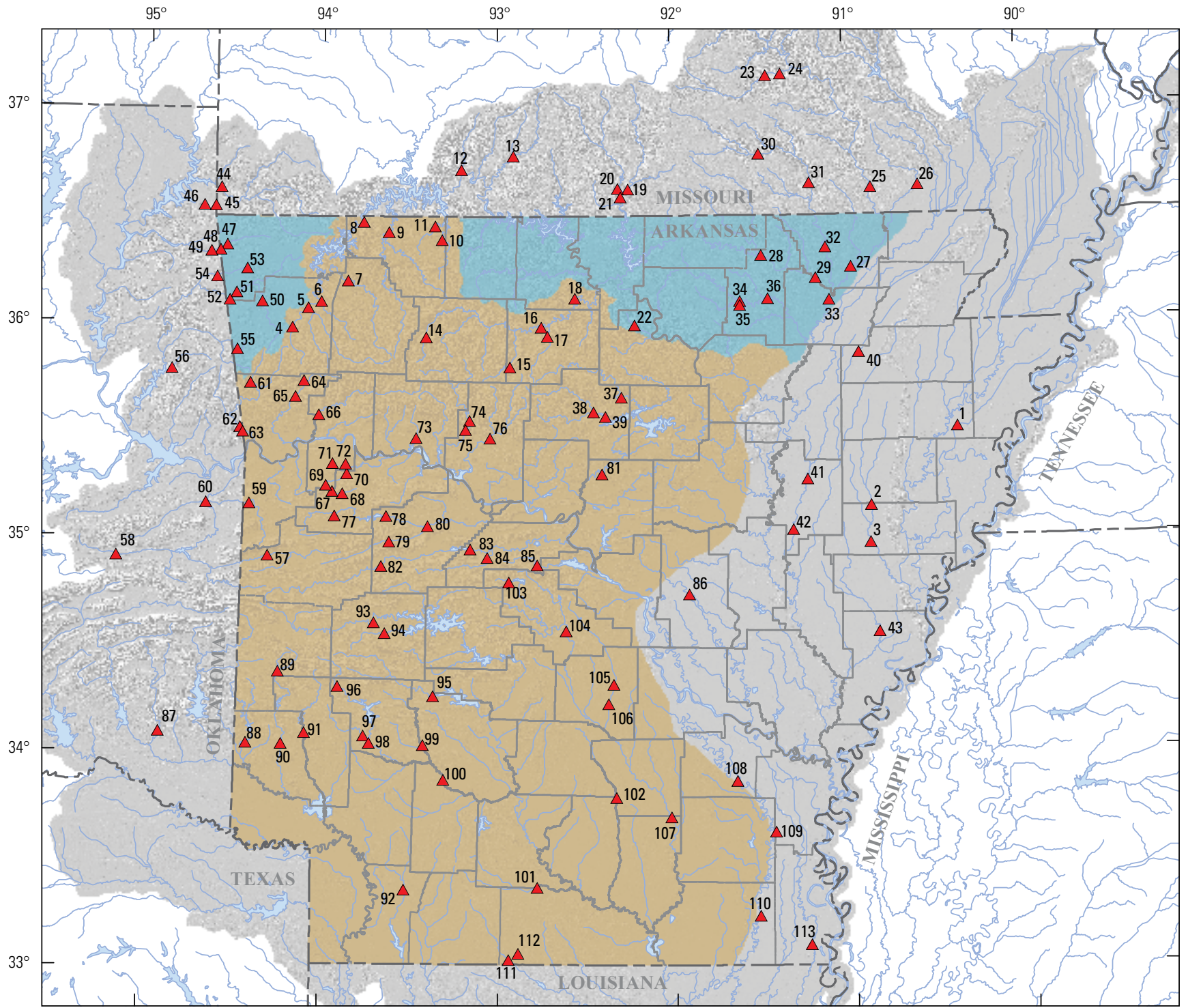

Base from the U.S. Geological Survey digital data, 2011, 1:100,000 USA Contiguous Albers Equal Area Conic USGS version North American Datum 1983

EXPLANATION

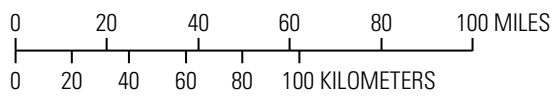

Harmonic mean flow region 1

Harmonic mean flow region 2

Shaded relief derived from U.S. Geological Survey

National Elevation Dataset, 10-meter grid (2011) -

Elevation data for basins in Arkansas used for analysis and regionalization of dry season mean monthly flow and harmonic mean flow

$92 \Delta$ Selected U.S. Geological Survey streamflow gage used for analysis and regionalization of dry season mean monthly flow and harmonic

mean flow in Arkansas with map identification number (appendix 1)

Figure 1. U.S. Geological Survey streamflow gages used for dry season mean monthly flow and harmonic mean flow regressions. 


\section{Regression Techniques}

Ordinary-least-squares (OLS) regressions were used to develop initial multiple-linear-regression (MLR) equations that were used for the initial analysis of streamflow data. Final equations for regional regressions were developed using weighted-least-squares (WLS) regressions. Logarithmic transformations (base 10) were used on all response variables (mean monthly flow and QAH) and tested for select explanatory variables (table 1) for the final regression equations. Logarithmic transformations were applied based on graphical comparisons of response variables and explanatory variables. Only drainage area was log transformed for the final regression equations. Other transformations were used for select explanatory variables (percent Ordovician and Mississippian) as necessary to increase linearity between the response variable and explanatory variables. The response variable was assumed to be a linear function of the explanatory variables.

MLR equations followed the general form

$$
Y_{i}=b_{0}+b_{1} X_{1}+b_{2} X_{2}+\cdots+b_{n} X_{n}+e_{i}
$$

where

$$
\begin{aligned}
& Y_{i} \text { is the response variable for site } i, \\
& X_{1} \text { to } X_{n} \begin{array}{l}
\text { are the } \mathrm{n} \text { explanatory variables for site } i, \\
b_{0} \text { to } b_{n}
\end{array} \\
& \text { are the } \mathrm{n}+1 \text { regression model coefficients, } \\
& \text { and }
\end{aligned} \quad \begin{aligned}
\text { is the residual error for site } i .
\end{aligned}
$$

A base-10 logarithmic transformation of the MLR has the form of

$$
\log Y_{i}=b_{0}+b_{1} \log X_{1}+b_{2} \log X_{2}+\cdots+b_{n} \log X_{n}+e_{i}
$$

where

$$
\begin{gathered}
\log \quad \text { is the base-10 logarithmic transformation of } \\
\text { the variable. }
\end{gathered}
$$

The algebraic equivalence of equation 2 after transformation back to its original units is

$$
Y_{i}=10^{b 0} X_{1}^{b 1} X_{2}^{b 2} \ldots X_{n}^{b n} 10^{e i}
$$

Tasker (1980) reported that OLS regression assumes that the time-sampling variance in the response-variable estimates is the same for each streamflow gage used in the analysis. As a result, this would imply that all observations of the response variable are equally reliable. This assumption is not always satisfied in hydrologic regressions because of the reliability of the record available for computation of the response variable based on the length of the observed streamflow record (Tasker,

\begin{tabular}{|c|c|c|c|c|c|c|c|c|c|c|c|c|c|c|c|c|c|}
\hline \multicolumn{18}{|c|}{ Dry season mean monthly streamflow } \\
\hline \multicolumn{9}{|c|}{ Drainage area } & \multicolumn{9}{|c|}{ Mean dry season total runoff } \\
\hline \multicolumn{2}{|c|}{ Minimum } & $\begin{array}{c}\text { First } \\
\text { quartile }\end{array}$ & \multicolumn{2}{|c|}{ Median } & Mean & $\begin{array}{c}\text { Third } \\
\text { quartile }\end{array}$ & \multicolumn{2}{|c|}{ Maximum } & \multicolumn{2}{|c|}{ Minimum } & $\begin{array}{c}\text { First } \\
\text { quartile }\end{array}$ & Median & \multicolumn{2}{|c|}{ Mean } & $\begin{array}{c}\text { Third } \\
\text { quartile }\end{array}$ & \multicolumn{2}{|c|}{ Maximum } \\
\hline 4.1 & & 89.0 & 241 & & 464 & 528 & 7,35 & & 3.6 & & 4.0 & 4.3 & & 4.3 & 4.6 & & 5.6 \\
\hline \multicolumn{18}{|c|}{ Harmonic mean flow region 1} \\
\hline \multicolumn{6}{|c|}{ Drainage area } & \multicolumn{6}{|c|}{ Base-flow index } & \multicolumn{6}{|c|}{ Slope1085 } \\
\hline $\begin{array}{l}\text { Mini- } \\
\text { mum }\end{array}$ & $\begin{array}{c}\text { First } \\
\text { quar- } \\
\text { tile }\end{array}$ & $\begin{array}{l}\text { Me- } \\
\text { dian }\end{array}$ & Mean & $\begin{array}{c}\text { Third } \\
\text { quar- } \\
\text { tile }\end{array}$ & $\begin{array}{c}\text { Maxi- } \\
\text { mum }\end{array}$ & $\begin{array}{l}\text { Mini- } \\
\text { mum }\end{array}$ & $\begin{array}{c}\text { First } \\
\text { quar- } \\
\text { tile }\end{array}$ & $\begin{array}{l}\text { Me- } \\
\text { dian }\end{array}$ & Mean & $\begin{array}{c}\text { Third } \\
\text { quar- } \\
\text { tile }\end{array}$ & $\begin{array}{c}\text { Maxi- } \\
\text { mum }\end{array}$ & $\begin{array}{l}\text { Mini- } \\
\text { mum }\end{array}$ & $\begin{array}{c}\text { First } \\
\text { quar- } \\
\text { tile }\end{array}$ & $\begin{array}{l}\text { Me- } \\
\text { dian }\end{array}$ & Mean & $\begin{array}{l}\text { Third } \\
\text { quar- } \\
\text { tile }\end{array}$ & $\begin{array}{c}\text { Maxi- } \\
\text { mum }\end{array}$ \\
\hline 8.0 & 99.8 & 304 & 779 & 784 & 7,350 & 0.3 & 0.4 & 0.5 & 0.5 & 0.5 & 0.7 & 2.0 & 7.2 & 9.2 & 15.1 & 17.2 & 95.8 \\
\hline \multicolumn{18}{|c|}{ Harmonic mean flow region 2} \\
\hline \multicolumn{6}{|c|}{ Drainage area } & \multicolumn{6}{|c|}{ Base-flow index } & \multicolumn{6}{|c|}{ Percent Ordovician and Mississippian } \\
\hline $\begin{array}{l}\text { Mini- } \\
\text { mum }\end{array}$ & $\begin{array}{l}\text { First } \\
\text { quar- } \\
\text { tile }\end{array}$ & $\begin{array}{l}\text { Me- } \\
\text { dian }\end{array}$ & Mean & $\begin{array}{l}\text { Third } \\
\text { quar- } \\
\text { tile }\end{array}$ & $\begin{array}{c}\text { Maxi- } \\
\text { mum }\end{array}$ & $\begin{array}{c}\text { Mini- } \\
\text { mum }\end{array}$ & $\begin{array}{l}\text { First } \\
\text { quar- } \\
\text { tile }\end{array}$ & $\begin{array}{l}\text { Me- } \\
\text { dian }\end{array}$ & Mean & $\begin{array}{l}\text { Third } \\
\text { quar- } \\
\text { tile }\end{array}$ & $\begin{array}{l}\text { Maxi- } \\
\text { mum }\end{array}$ & $\begin{array}{c}\text { Mini- } \\
\text { mum }\end{array}$ & $\begin{array}{l}\text { First } \\
\text { quar- } \\
\text { tile }\end{array}$ & $\begin{array}{l}\text { Me- } \\
\text { dian }\end{array}$ & Mean & $\begin{array}{l}\text { Third } \\
\text { quar- } \\
\text { tile }\end{array}$ & $\begin{array}{c}\text { Maxi- } \\
\text { mum }\end{array}$ \\
\hline 4.1 & 83.0 & 210 & 341 & 410 & 2,090 & 0.1 & 0.2 & 0.2 & 0.3 & 0.3 & 0.4 & 0.0 & 0.0 & 6.0 & 24.8 & 47.0 & 100 \\
\hline
\end{tabular}
1980; Eash and Barnes, 2012). The WLS regression adjusts for the variation in the reliability of the response-variable estimates by using a weight for each streamflow gage to account for differences in the period of record available for computation of the response variable (Eng and others, 2009; Eash and Barnes, 2012).

Table 1. Range of basin characteristic values used to develop dry season mean monthly flow and harmonic mean flow regression equations for unregulated streams in Arkansas.

[Slope1085, slope of channel in feet per mile between points at 10 and 85 percent of the longest flow path from the outlet] 
Candidate regressions were selected for WLS by testing all possible combinations of the 42 explanatory variables (app. 2) using the allReg() function contained within the "USGSwsStats" package (Lorenz, 2013b) for R, an integrated suite of software facilities for data manipulation, calculation, and graphical display (R Core Team, 2014). The best candidate regression equations were selected based on the lowest values of Mallow's $\mathrm{C}_{\mathrm{p}}$ and analysis of multicollinearity using the variance inflation factor (Helsel and Hirsch, 2002). The WLS regressions were repeatedly performed in $\mathrm{R}$ ( $\mathrm{R}$ Core Team, 2014) to reduce the number of explanatory variables to those significant at the 95-percent confidence interval. Regression diagnostics, including residual standard error, coefficient of determination $\left(\mathrm{R}^{2}\right)$, multicollinearity, Cook's $\mathrm{D}$, leverage, and graphical relations (Helsel and Hirsch, 2002), were used to evaluate the performance of WLS regressions.

\section{Dry Season Mean Monthly Flow Data}

Daily-mean streamflow data for 91 USGS streamflow gages were used to compute monthly-mean flows. A mean monthly flow is computed as the arithmetic mean of all monthly-mean flows for a given month of the year for a selected period of record for a streamflow gage. A monthlymean flow is computed as the arithmetic mean of the dailymean flows for a given month of the year. Regression analysis was performed with ensembles for five critical, dry season months, July through November.

Five regression equations were developed for the calculation of dry season mean monthly flows during the months of July through November. All five equations contain at least one significant explanatory variable (table 1 ) derived from a previous runoff study in Arkansas (Pugh and Westerman, 2014). The median number of years of record used for calculation of dry season mean monthly flow at the 91 streamflow gages was 43 (app. 1). Equations for estimation of dry season mean monthly flow are applicable only at ungaged, unaltered stream locations in Arkansas.

\section{Harmonic Mean Flow Data}

Equations for two regions were found to be statistically significant for developing regression equations for estimating harmonic mean flow at selected ungaged basins in Arkansas. Of the 93 streamflow gages used for QAH (fig. 1; app. 1), 33 and 60 streamflow gages were used for the first and second regions, respectively. The median number of years of data used for QAH calculations in the WLS regression analysis was 34 for region 1 and 43 for region 2 (app. 1). The WLS regression equations used to estimate QAH are applicable only to ungaged, unaltered streams in region 1 and region 2.
For QAH calculations (app. 3), the study area is composed of the Springfield-Salem Plateaus (Arkansas and Missouri), Boston Mountains, Arkansas Valley, Ouachita Mountains (Arkansas and Oklahoma), and West Gulf Coastal Plain (Arkansas) physiographic sections (fig. 2). A QAH value was calculated for all streamflow gages used in the regression equations using the USGS "DVstats" package (Lorenz, 2013a) in R software (R Core Team, 2014), which is based on the EPA's computer program for estimating design flows for use in water-quality studies (DFLOW) (Rossman, 1990b). The QAH statistic generally is smaller than the arithmetic mean statistic, gives more weight to lower flows, and is corrected for daily flow values of zero (Rossman, 1990a). The QAH is calculated as

where

$$
Q A H=\left(\frac{N_{n z}}{N_{t}}\right)\left(\frac{N_{n z}}{\sum_{i=1}^{N_{n z}}\left(\frac{1}{Q_{i}}\right)}\right)
$$

$Q_{i} \quad$ is the daily mean streamflow, in cubic feet per second,

$N_{n z} \quad$ is the number of nonzero days, and

$N_{t} \quad$ is the total number of $Q_{i}$ values.

If $N_{n z}$ equals $N_{t}$, QAH is equal to the reciprocal of the mean of the reciprocals of all $Q_{i}$.

\section{Regionalization of Harmonic Mean Flow Data}

Regionalization is a statistical framework used to estimate statistics at ungaged stream locations from statistics calculated at USGS streamflow gages (Ries, 2007). Regionalization techniques are used because streamflow statistics can vary substantially between regions because of differences in geology, climate, and physical characteristics. Regionalization of low-flow statistics in Arkansas was first attempted by Hines (1965). Subsequently, Ludwig and Tasker (1993) divided the western two-thirds of Arkansas into three low-flow regions of well sustained and poorly sustained low flow. Minor changes were made to the existing low-flow statistical regions by Funkhouser and others (2008) attributable to enhanced GIS capabilities for spatial data processing. No regional methods for mean flow estimation have been developed for Arkansas prior to this study.

Streamflow gages used for QAH were located on streams in Arkansas, Oklahoma, or Missouri. An initial OLS regression was performed on all gages selected for inclusion in a statewide regression analysis. Residuals from the statewide OLS regression were spatially analyzed and indicated the need for equations in two regions. 


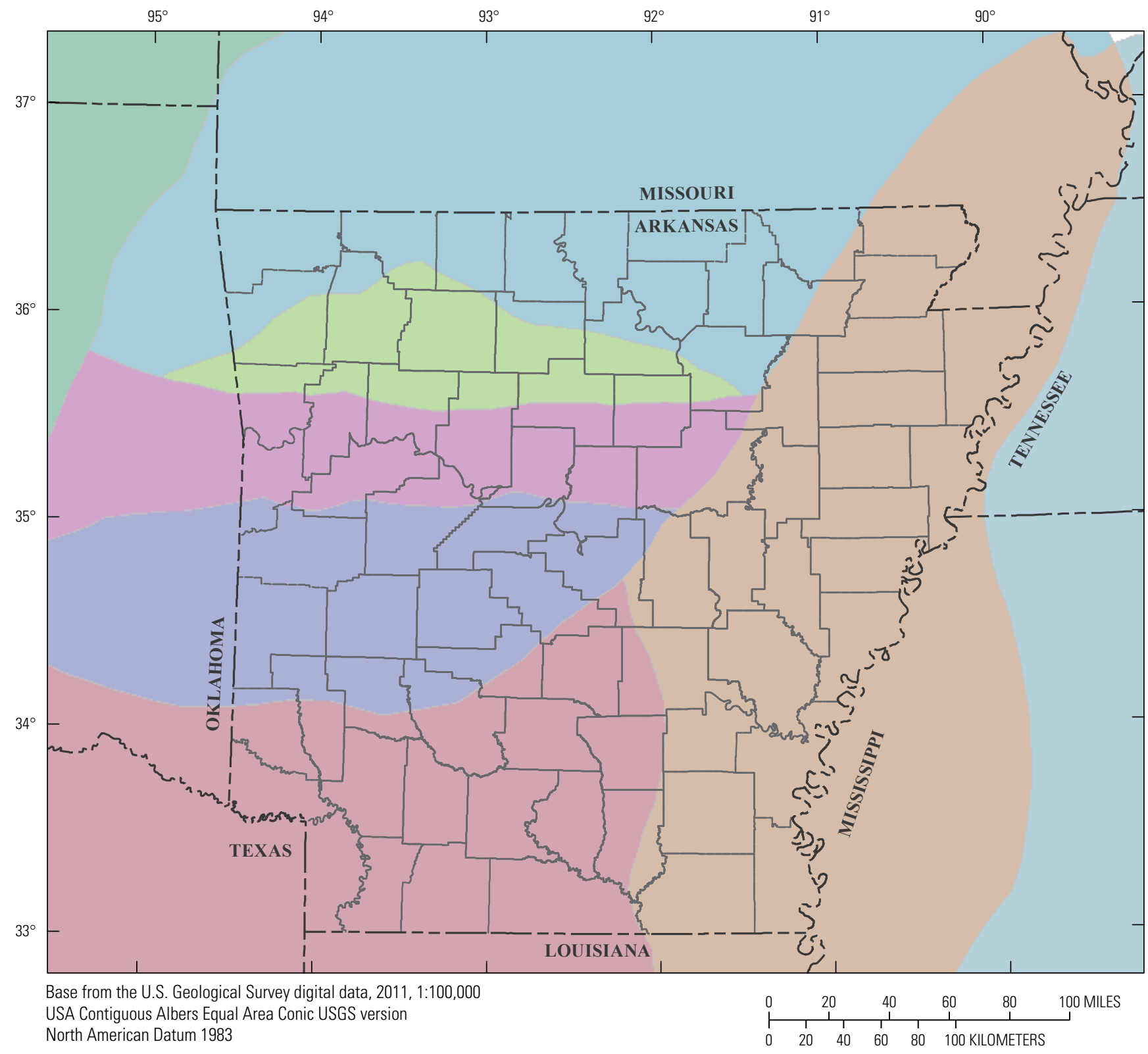

EXPLANATION

Physiographic section (Fenneman, 1946)

Arkansas Valley

Boston Mountains

East Gulf Coastal Plain

Mississippi Alluvial Plain

Osage Plains

Ouachita Mountains

Springfield-Salem Plateaus

West Gulf Coastal Plain

Figure 2. Physiographic sections of Arkansas. 
Region 1 includes a small part of Arkansas that is located exclusively in the northern part of the State (fig. 1), mostly in the Springfield-Salem Plateaus (figs. 1 and 2). The region is underlain by a series of limestone and dolomite units and therefore exhibits numerous karst features that affect regional hydrology and groundwater/surface-water interaction (Ludwig and Tasker, 1993). Streams in region 1 often are sustained by numerous springs. The well-sustained flows from numerous springs are indicative of a regional source of water that is supplemented during extended periods of precipitation by a local component of groundwater recharge (Ludwig and Tasker, 1993).

Region 2 includes the rest of the State excluding the Mississippi Alluvial Plain. The northern part of region 2 (fig. 1) includes the Boston Mountains, Arkansas Valley, Ouachita Mountains, and parts of the Springfield Plateau physiographic sections (fig. 2; Fenneman, 1946). Region 2 is underlain or mantled by consolidated rocks consisting primarily of sandstones and shales. The primary porosity and permeability of these sandstones and shales have been greatly reduced by compaction and deep burial; therefore, only limited amounts of groundwater are available from secondary openings including joints and fractures. The fractures, however, do not supply the base flows of streams to the extent that numerous springs do in region 1 (Ludwig and Tasker, 1993).

The southern part of region 2 is located in the West Gulf Coastal Plain physiographic section, which is underlain by unconsolidated deposits composed of sand, silt, and clay. The streams in the southern part of region 2 generally do not have sustained base flow because (1) the stream channels are not incised deeply enough to intercept the water table, and (2) the surficial deposits typically have low permeability and porosity (Ludwig and Tasker, 1993).

\section{Dry Season Mean Monthly Flow and Harmonic Mean Flow Regression Equations}

Observed values of dry season mean monthly flows and QAH (app. 3) computed from daily-mean flow data were used with basin characteristics (app. 2) to identify significant explanatory variables (table 1) for multiple-linear-regression equations (tables 2 and 3) to estimate predicted values of dry season mean monthly flows and QAH. Predicted values were compared to observed values to evaluate the performance of the WLS regression equations. The widely used residual standard error (RSE) and adjusted correlation coefficient (Helsel and Hirsch, 2002) diagnostics of the regression analysis are provided for their respective regression equations (tables 2 and
3). Normalized root mean square error (NRMSE) and percent bias (PBIAS) were additional metrics computed for all of the regression equations. Values for normalized root mean square error ranged from 33.6 to 38.4 percent for dry season mean monthly flow (table 2) and from 29.2 to 45.8 percent for QAH (table 3 ). The NRMSE is computed as

$$
N R M S E=100 \frac{\sqrt{\frac{1}{N} \sum_{i=1}^{N}\left(\text { predicted }_{i}-\text { observed }_{i}\right)^{2}}}{s d\left(\text { observed }_{i}\right)}
$$

where

$$
\begin{aligned}
s d & \text { is standard deviation, } \\
N & \text { is the total number of comparisons, and } \\
i & \text { is the individual value. }
\end{aligned}
$$

and PBIAS as

$$
\text { PBIAS }=100 \frac{\sum_{i=1}^{N}\left(\text { predicted }_{i}-\text { observed }_{i}\right)}{\sum_{i=1}^{N} \text { observed }_{i}}
$$

Of the 47 basin characteristics (app. 2), 5 were found to be significant explanatory variables for dry season mean monthly flow and QAH regressions for regions 1 and 2: (1) drainage area; (2) base-flow index; (3) slope 1085; the stream slope computed as the change in elevation in feet between points at 10 and 85 percent of the length in miles of the longest flow path from the outlet, divided by length between the points; (4) mean dry season total runoff; and (5) percent Mississippian and Ordovician surficial geology (app. 3). An example regression equation for QAH for region 2 is:

$$
\log Q A H=A+b \log D A+c O M+d B F I
$$

where

$$
\begin{aligned}
& \log \text { is the base-10 logarithmic transformation of } \\
& \text { the variable, } \\
& Q A H \text { is the harmonic mean flow, } \\
& A \text { is the intercept, } \\
& D A \text { is the drainage area, in square miles, } \\
& O M \text { is the percent Ordovician and Mississippian } \\
& \text { surficial geology divided by } 100+1, \\
& B F I \text { is the base-flow index, and } \\
& \text { are the coefficients of regression for the } \\
& \text { basin characteristics used as explanatory } \\
& \text { variables, }
\end{aligned}
$$

Or, in the algebraic equivalence of equation 7 , the regression equation can be transformed back to the original units

$$
Q A H=10^{A}(D A)^{b} 10^{c(O M)} 10^{d(B F I)}
$$


Table 2. Regression equations and ancillary regression diagnostics for dry season mean monthly flow estimation in Arkansas.

[DRNAREA, drainage area; DryTotRun, mean dry season total runoff; RSE, residual standard error; $\mathrm{R}^{2}$, correlation coefficient; NRMSE, normalized root mean square error; PBIAS, percent bias]

Regression equation $\quad \begin{gathered}\text { Number of } \\ \text { streamflow } \\ \text { gages used } \\ \text { to develop } \\ \text { equation }\end{gathered} \quad$ RSE $\quad \begin{gathered}\text { Adjusted } \\ R^{2}\end{gathered} \begin{gathered}\text { NRMSE } \\ \text { (percent) }\end{gathered} \quad \begin{gathered}\text { PBIAS } \\ \text { (percent) }\end{gathered}$

Weighted-least-squares regression equation for July mean monthly streamflow
July $=10^{-1.441}$ DRNAREA ${ }^{1.022} 10^{0.229 \text { (DryTotRun) }}$
91
0.198
$0.89 \quad 34.1$
$-1.1$

Weighted-least-squares regression equation for August mean monthly streamflow

$$
\text { August }=10^{-1.921} \text { DRNAREA }{ }^{1.092} 10^{0.250 \text { (DryTotRun) }}
$$

91

0.262

0.84

38.4

$-1.2$

Weighted-least-squares regression equation for September mean monthly streamflow

September $=10^{-1.556}$ DRNAREA $^{0.975} 10^{0.274(\text { DryTotRun) }}$

91

0.197

$0.88 \quad 33.6$

$-0.2$

Weighted-least-squares regression equation for October mean monthly streamflow

October $=10^{-0.902}$ DRNAREA ${ }^{0.929} 10^{0.174(\text { DryTotRun) }}$

91

0.193

$0.87 \quad 35.6$

0.3

Weighted-least-squares regression equation for November mean monthly streamflow

November $=10^{-0.446}$ DRNAREA ${ }^{0.865} 10^{0.179(\text { DryTotrRun) }}$

$91 \quad 0.180$

0.87

35.0

1.0

Table 3. Regression equations and ancillary regression diagnostics for harmonic mean flow estimation in two regions identified in Arkansas.

[QAH, harmonic mean flow; DRNAREA, drainage area; BFI, base flow index; Slope1085, slope of channel in feet per mile between points at 10 and 85 percent of the longest flow path from the outlet; ORDOMISS, percent surficial geology Ordovician and Mississippian rocks divided by 100 plus 1 ; RSE, residual standard error; $\mathrm{R}^{2}$, correlation coefficient; NRMSE, normalized root mean square error; PBIAS, percent bias]

\begin{tabular}{|c|c|c|c|c|c|}
\hline Regression equation & $\begin{array}{c}\text { Number of } \\
\text { streamflow } \\
\text { gages used to } \\
\text { develop equation }\end{array}$ & RSE & Adjusted R ${ }^{2}$ & $\begin{array}{c}\text { NRMSE } \\
\text { (percent) }\end{array}$ & $\begin{array}{c}\text { PBIAS } \\
\text { (percent }\end{array}$ \\
\hline \multicolumn{6}{|l|}{ Weighted-least-squares regression equation for region 1} \\
\hline QAH $=10^{-2.733}$ DRNAREA $A^{1.320} 10^{2.690(B F I)} 10^{0.015(\text { Slope } 1085)}$ & 33 & 0.233 & 0.93 & 29.2 & -0.8 \\
\hline \multicolumn{6}{|l|}{ Weighted-least-squares regression equation for region 2} \\
\hline QAH $=10^{-3.654}$ DRNAREA $^{1.022} 10^{1.132 \text { (ORDOMISS) }} 10^{2.431 \text { (BFI) }}$ & 60 & 0.295 & 0.82 & 45.8 & -4.6 \\
\hline
\end{tabular}




\section{Limitations}

The final regression equations are applicable only to streams in Arkansas that are unaltered. The range of values for explanatory variables used to develop the final regression equations for this report is listed in table 1. A measure of the uncertainty associated with the regression of dry season mean monthly flows and QAH is the prediction interval. A prediction interval is the probability that the actual value of the estimated statistic will be within a specific margin of error (Helsel and Hirsch, 2002). For a 90-percent prediction interval, the true streamflow statistic has a 90-percent probability of being within the margin of error. The following equation described by Eash and Barnes (2012), which is modified from Tasker and Driver (1988), can be used to compute the 90-percent prediction interval for the true value of a streamflow statistic for an ungaged site:

$$
\frac{Q}{T}<Q<Q T
$$

where

$Q \quad$ is the dry season mean monthly flow or $\mathrm{QAH}$ predicted for the ungaged site from the regression equation, and $T$ is computed as

$$
T=10^{\left[t_{(a / 2, n-p)} S_{i}\right]}
$$

where

$t_{(\alpha 2, n-t)} \quad$ is the critical value from the student's $t$-distribution at alpha level $\alpha(\alpha=0.10$ for the 90-percent prediction intervals; critical values may be obtained in many statistics textbooks (Iman and Conover, 1983),

$n-p \quad$ is the degree of freedom with $n$ streamflow gages included in the regression analysis and $p$ parameters in the equation (the number of explanatory variables plus one), and

$S_{i} \quad$ is the standard error of prediction for site $i$ and is computed as

$$
S_{i}=\left[\mathrm{MEV}+X_{i} U X_{i}^{\prime}\right]^{0.5}
$$

where

$M E V \quad$ is the mean squared error from WLS regression equations developed for this study using a user-defined weighting matrix;

$X_{i} \quad$ is the row vector for the streamflow gage $i$, starting with the number 1 , followed by the logarithmic values of the basin characteristics used in the regression;

$U \quad$ is the covariance matrix for the annual or seasonal regression coefficients; and

$X_{i}^{\prime} \quad$ is the matrix algebra transpose of the $X i$ (Ludwig and Tasker, 1993; Ries and Friesz, 2000).

The $X_{i} U X_{i}^{\prime}$ in equation 11 also is referred to as the sampling error variance. The values of $t_{(\alpha / 2, n-p)}$ and $U$ needed to determine prediction intervals for estimates obtained by the regression equations in tables 2 and 3 are listed in table 4 . 
Table 4. Values needed to determine the 90-percent prediction intervals for estimates obtained from regression equations using covariance matrices in A rkansas.

$\left[\mathrm{t}_{(\alpha / 2, \mathrm{n}-\mathrm{p})}\right.$, the critical value from Students $\mathrm{t}$-distribution for the 90-percent probability used in equation 10; MEV, regression model error variance used in equation 11; U, covariance matrix as used in equation 10; $\log \mathrm{DA}, \log 10$ transformed drainage area; DryTotRun, mean dry season total runoff; BFI, base-flow index; Slope1085, slope of channel in feet per mile between points at 10 and 85 percent of the longest flow path from the outlet; OM, percent surficial geology Ordovician and Mississippian divided by 100 plus 1]

\begin{tabular}{|c|c|c|c|c|c|c|}
\hline \multirow{2}{*}{$\begin{array}{c}\text { Response variable } \\
\text { July mean monthly streamflow } \\
\end{array}$} & \multirow{2}{*}{$\begin{array}{l}t_{(\alpha / 2, n-p)} \\
1.8467 \\
\end{array}$} & \multirow{2}{*}{$\begin{array}{c}\text { MEV } \\
0.0452\end{array}$} & & \multicolumn{3}{|c|}{$\mathbf{U}$} \\
\hline & & & & (Intercept) & $\log \mathrm{DA}$ & DryTotRun \\
\hline & & & (Intercept) & 0.04535396 & -0.00365853 & -0.00820081 \\
\hline & & & DryTotRun & -0.00820081 & -0.00001740 & 0.00188411 \\
\hline
\end{tabular}

\begin{tabular}{lllllll}
\hline August mean monthly streamflow & $\mathbf{1 . 6 0 6 3}$ & $\mathbf{0 . 0 7 0 0}$ & & (Intercept) & logDA & DryTotRun \\
\hline & & (Intercept) & 0.07906513 & -0.00637789 & -0.01429639 \\
& & & logDA & -0.00637789 & 0.00263511 & -0.00003034 \\
& & & DryTotRun & -0.01429639 & -0.00003034 & 0.00328455
\end{tabular}

\begin{tabular}{lllllll}
\hline September mean monthly streamflow & $\mathbf{1 . 7 9 4 4}$ & $\mathbf{0 . 0 4 5 7}$ & & (Intercept) & logDA & DryTotRun \\
\hline & & (Intercept) & 0.04486505 & -0.00361909 & -0.00811240 \\
& & logDA & -0.00361909 & 0.00149528 & -0.00001722 \\
& & & DryTotRun & -0.00811240 & -0.00001722 & 0.00186380
\end{tabular}

\begin{tabular}{lllllll}
\hline October mean monthly streamflow & $\mathbf{1 . 9 0 4 2}$ & $\mathbf{0 . 0 4 7 4}$ & & (Intercept) & logDA & DryTotRun \\
\hline & & (Intercept) & 0.04288050 & -0.00345901 & -0.00775356 \\
& & logDA & -0.00345901 & 0.00142914 & -0.00001645 \\
& & & DryTotRun & -0.00775356 & -0.00001645 & 0.00178136
\end{tabular}

\begin{tabular}{lllllll}
\hline November mean monthly streamflow & $\mathbf{2 . 2 2 5 7}$ & $\mathbf{0 . 0 3 8 1}$ & & (Intercept) & logDA & DryTotRun \\
\hline & & (Intercept) & 0.03741506 & -0.00301813 & -0.00676531 \\
& & logDA & -0.00301813 & 0.00124698 & -0.00001436 \\
& & & DryTotRun & -0.00676531 & -0.00001436 & 0.00155431
\end{tabular}

\begin{tabular}{|c|c|c|c|c|c|c|c|}
\hline Harmonic mean flow region 1 & 1.6937 & 0.0641 & & (Intercept) & $\log \mathrm{DA}$ & BFI & Slope 1085 \\
\hline & & & (Intercept) & 0.14021140 & -0.01779832 & -0.16399111 & -0.00097720 \\
\hline & & & $\log \mathrm{DA}$ & -0.01779832 & 0.00820252 & -0.01328758 & 0.00021931 \\
\hline & & & Slope1085 & -0.00097720 & 0.00021931 & 0.00047734 & 0.00001313 \\
\hline \multirow{4}{*}{ Harmonic mean flow region 2} & & & (Intercept) & 0.08792426 & -0.02244803 & -0.01608324 & -0.04605076 \\
\hline & & & $\log \mathrm{DA}$ & -0.02244803 & 0.01227426 & -0.00007389 & -0.03009622 \\
\hline & & & $\mathrm{OM}$ & -0.01608324 & -0.00007389 & 0.01884845 & -0.02850505 \\
\hline & & & BFI & -0.04605076 & -0.03009622 & -0.02850505 & 0.62346886 \\
\hline
\end{tabular}




\section{Summary}

The U.S. Geological Survey (USGS), in cooperation with the Arkansas Department of Environmental Quality (ADEQ), Southwestern Energy, the Arkansas Natural Resources Commission, and the Arkansas Game and Fish Commission, developed regression equations for estimation of dry season mean monthly flows and harmonic mean flows (QAH) that are representative of natural streamflow conditions at selected ungaged basins in Arkansas. Observed values of dry season mean monthly flow and QAH computed from daily-mean flow data were used with basin characteristics to identify significant explanatory variables for multiple-linear-regression equations to estimate predicted values of dry season mean monthly flow and QAH. These two streamflow statistics are routinely needed for ungaged streams for water-quality regulation, stream-related structural design, wastewater management, and stream-hazard identification. Dry season mean monthly flow and QAH are useful for setting criteria for wastewater-treatment plant effluent and allowable pollutant loads to meet water-quality standards for human health criteria, irrigation, recreation, and wildlife conservation.

Five dry season mean monthly flow regression equations and two QAH regression equations were developed using dry season mean monthly flow and QAH established for 91 and 93 USGS continuous-record streamflow gaging stations, respectively. The dry season in Arkansas is defined as the months of July through November. For QAH calculations and regression equations, the study area is composed of the Springfield-Salem Plateaus (Arkansas and Missouri), Boston Mountains, Arkansas Valley, Ouachita Mountains (Arkansas and Oklahoma), and West Gulf Coastal Plain (Arkansas) physiographic sections. All streamflow-gaging stations used to compute dry season mean monthly flows were located within Arkansas. Continuousrecord streamflow-gaging stations used for this study had a minimum of 12 water years of daily-mean flow data. Basin characteristics that included geologic, climatic, physical, and statistical variables were computed for each basin.

The median number of years used for dry season mean monthly flow calculation was 43. Regression equations for mean monthly flow were applicable only to stream sites located throughout Arkansas. The regression equations for dry season mean monthly flow and QAH are applicable only to unaltered streams where flows were not significantly affected by regulation, diversion, or urbanization.

Equations for two regions were found to be statistically significant for developing regression equations for estimating QAH at ungaged basins in Arkansas. Of the 93 continuousrecord streamflow-gaging stations used for QAH, 33 and 60 streamflow-gaging stations were used for the first and second regions, respectively. The median number of years of data used for QAH calculations in the weighted-least-squares regression analysis was 34 for region 1 and 43 for region 2 . The weightedleast-squares regression equations used to estimate QAH were applicable only to streams in their respective regions, region 1 and region 2 .
Residual standard error, adjusted correlation coefficient, normalized root mean square error, and percent bias were used to evaluate the performance of the regression equations developed for this study. Values for normalized root mean square error ranged from 33.6 to 38.4 percent for dry season mean monthly flow and from 29.2 to 45.8 percent for QAH. Equations developed during this study also are intended for delivery in the USGS StreamStats program. StreamStats will provide users the ability to estimate dry season mean monthly flow, QAH, and 90 percent prediction intervals for ungaged streams in Arkansas.

\section{Selected References}

Acreman, W.C., and Wiltshire, S.E., 1987, Identification of regions for regional flood frequency analysis [abs.]: EOS, v. 68 , no. 44 , p. $1-262$.

Eash, D.A., and Barnes, K.K., 2012, Methods for estimating selected low-flow frequency statistics and harmonic mean flows for streams in Iowa: U.S. Geological Survey Scientific Investigations Report 2012-5171, 99 p. (Also available at http://pubs.usgs.gov/sir/2012/5171/.)

Eng, Ken, Chen, Yin-Yu, and Kiang, J.E., 2009, User's guide to the weighted-multiple-linear-regression program (WREG version 1.0): U.S. Geological Survey Techniques and Methods, book 4, chap. A8, 21 p. (Also available at http://pubs. usgs.gov/tm/tm4a8/.)

Falcone, J.A., Carlisle, D.M., Wolock, D.M., and Meador, M.R., 2010, GAGES: A stream gage database for evaluating natural and altered flow conditions in the conterminous United States: Ecology, v. 91, no. 2, p. 621, a data paper in Ecological Archives E091-045-D1.

Fenneman, N.M., 1946, Physical divisions of the United States: U.S. Geological Survey map, scale 1:7,000,000, 1 sheet.

Funkhouser, J.E., Eng, Ken, and Moix, M.W., 2008, Low-flow characteristics and regionalization of low-flow characteristics for selected streams in Arkansas: U.S. Geological Survey Scientific Investigations Report 2008-5065, 161 p. (Also available at http://pubs.usgs.gov/sir/2008/5065/.)

Haley, B.R., Glick, E.E., Bush, W.V., Clardy, B.F., Stone, C.G., Woodward, M.B., and Zachry, D.L., 1993 Geologic map of Arkansas: U.S. Geological Survey, 1 sheet, scale 1:500,000.

Helsel, D.R., and Hirsch, R.M., 2002, Statistical methods in water resources: U.S. Geological Survey Techniques of Water-Resources Investigations, book 4, chap. A3, 510 p. (Also available at http://pubs.usgs.gov/twri/twri4a3/html/ pdf_new.html.)

Hines, M.S., 1965, Water-supply characteristics of selected Arkansas streams: Arkansas Geological Commission Water Resources Circular 9, 43 p. 
Iman, R.L., and Conover, W.J., 1983, A modern approach to statistics: New York, John Wiley and Sons, Inc., 497 p.

Jin, S., Yang, L., Danielson, P., Homer, C., Fry, J., and Xian, G. 2013, A comprehensive change detection method for updating the National Land Cover Database to circa 2011: Remote Sensing of Environment, v. 132, p. 159-175. (Also available at http://www.mrlc.gov/nlcd2011.php.)

Lorenz, D.L., 2013a, DVstats-An R package for managing daily-values data, version 0.1: U.S. Geological Survey, accessed March 1, 2014, at https://github.com/USGS-R/ DVstats.

Lorenz, D.L., 2013b, USGSwsStats-An R package for the analysis of hydrologic data, version 0.6: U.S. Geological Survey, accessed March 1, 2014, at https://github.com/ USGS-R/USGSwsStats.

Ludwig, A.H., and Tasker, G.D., 1993, Regionalization of low-flow characteristics of Arkansas streams: U.S. Geological Survey Water-Resources Investigations Report 93-4013, $26 \mathrm{p}$.

PRISM Climate Group, 2012, PRISM climate data: Oregon State University, accessed on May 30, 2014, at http://www. prism.oregonstate.edu/.

Pugh, A.L., and Westerman, D.A., 2014, Mean annual, seasonal, and monthly precipitation and runoff in Arkansas, 1951-2011: U.S. Geological Survey Scientific Investigations Report 2014-5006, 40 p. (Also available at http:// dx.doi.org/10.3133/sir20145006.)

R Core Team, 2014, The R project for statistical computing: Vienna, Austria, The R Foundation for Statistical Computing, accessed March 1, 2014, at http://www.R-project.org/.

Reed, J.C., and Bush, C.A., 2005, Generalized geologic map of the United States, Puerto Rico, and the U.S. Virgin Islands: U.S. Geological Survey National Atlas of the United States. (Also available at http://pubs.usgs.gov/atlas/ geologic/.)

Ries, K.G., III, 2007, The National Streamflow Statistics Program-A computer program for estimating streamflow statistics for ungaged sites: U.S. Geological Survey Techniques and Methods, book 4, chap. A6, 37 p. (Also available at http://pubs.usgs.gov/tm/2006/tm4a6/pdf/tm4a6.pdf.)

Ries, K.G., and Friesz, P.J., 2000, Methods for estimating low-flow statistics for Massachusetts streams: U.S. Geological Survey Water-Resources Investigations Report 2000-4135, 81 p. (Also available at http://pubs.usgs.gov/ $\mathrm{wri} / \mathrm{wri} 004135 /$.

Rossman, L.A., 1990a, Design stream flows based on harmonic means: Journal of Hydraulic Engineering, v. 116, no. 7 , p. $946-950$
Rossman, L.A., 1990b, DFLOW user's manual: Cincinnati, Ohio, U.S. Environmental Protection Agency, Risk Reduction Engineering Laboratory, 26 p., accessed May 21, 2014, at http://nepis.epa.gov/Exe/ZyNET.exe/30001JEH. TXT?ZyActionD=ZyDocument\&Client=EPA\&Index $=1$ 986+Thru+1990\&Docs $=\&$ Query $=600890051 \% 20$ or $\% 20$ dflow\%20or\%20user's\%20or\%20manual\%20or\%20 rossman $\&$ Time $=\&$ EndTime $=\&$ SearchMethod $=1 \&$ TocRestr ict $=\mathrm{n} \&$ Toc $=\&$ TocEntry $=\& Q$ Field $=$ pubnumber $\% 5 \mathrm{E} \% 22600$ $890051 \% 22 \&$ QFieldYear $=\&$ QFieldMonth $=\& Q$ FieldDay $=\&$ UseQField=pubnumber\&IntQFieldOp $=1 \&$ ExtQFieldOp $=1$ $\& X m l Q u e r y=\& F i l e=D \% 3 \mathrm{~A} \% 5$ Czyfiles $\% 5$ Index $\% 20$ Data \%5C86thru90\%5CTxt\%5C00000005\%5C30001JEH.txt\&U ser $=$ ANONYMOUS\&Password $=$ anonymous $\&$ SortMethod $=$ $\mathrm{h} \%$ 7C \&MaximumDocuments $=10 \&$ FuzzyDegree $=0 \&$ Image Quality $=$ 75gg/r75g8/x150y150g16/i425\&Display $=\mathrm{p} \% 7 \mathrm{Cf}$ $\&$ DefSeekPage $=x \&$ SearchBack $=$ ZyActionL $\&$ Back $=$ ZyActi onS\&BackDesc $=$ Results $\% 20$ page $\&$ MaximumPages $=1 \& Z y$ Entry $=1 \&$ SeekPage $=\mathrm{x} \&$ ZyPURL .

Schwarz, G.E., and Alexander, R.B., 1995, STATe Soil GeOgraphic (STATSGO) database for the conterminous United States: U.S. Geological Survey Open-File Report 95-449, $95 \mathrm{p}$.

Tasker, G.D., 1980, Hydrologic regression with weighted least squares: Water Resources Research, v. 16, no. 6, p. 11071113 .

Tasker, G.D., and Driver, N.E., 1988, Nationwide regression models for predicting urban runoff water quality at unmonitored sites: Water Resources Bulletin, v. 24, no. 5, p. 10911101, accessed December 12, 2014, at http://onlinelibrary. wiley.com/doi/10.1111/j.1752-1688.1988.tb03026.x/pdf.

U.S. Department of Agriculture, 2001, STATe Soil GeOgraphic (STATSGO) database-Data use information (revised July 1994): Natural Resources Conservation Service, National Soil Survey Center, Miscellaneous Publication No. 1492, 110 p.

U.S. Geological Survey, 2001,USGS Water data for the Nation: National Water Information System: Web Interface, accessed March 21, 2014, at http://waterdata.usgs.gov/ nwis/.

U.S. Geological Survey, 2011, National elevation dataset: U.S. Geological Survey, accessed March 21, 2014, at http://ned. usgs.gov/.

U.S. Geological Survey, 2012a, Welcome to StreamStats-The StreamStats Program: U.S. Geological Survey, accessed May 30, 2013, at http://water.usgs.gov/osw/streamstats/ index.html.

U.S. Geological Survey, 2012b, Welcome to StreamStatsBasin characteristic definitions: U.S. Geological Survey, accessed May 30, 2013, at http://water.usgs.gov/osw/ streamstats/bcdefinitions 1.html. 
Appendixes 1-3 



\section{Appendix 1}

Table 1-1. U.S. Geological Survey streamflow gages used for regression analysis for dry season mean monthly flow and harmonic mean flow.

[fts/s, cubic feet per second; USGS, U.S. Geological Survey; Ark., Arkansas; Mo., Missouri; Okla., Oklahoma; --, gage was not used for the regression in the column heading for that station]

\begin{tabular}{|c|c|c|c|c|c|c|c|c|c|c|}
\hline $\begin{array}{c}\text { Map } \\
\text { identi- } \\
\text { fication } \\
\text { number }\end{array}$ & $\begin{array}{c}\text { Dry season } \\
\text { mean } \\
\text { monthly } \\
\text { streamflow } \\
\left(\mathrm{ft}^{3} / \mathrm{s}\right)\end{array}$ & $\begin{array}{c}\text { Harmonic } \\
\text { mean } \\
\text { flow } \\
\text { region } 1 \\
\left(\mathrm{ft}^{3} / \mathrm{s}\right)\end{array}$ & $\begin{array}{c}\text { Harmonic } \\
\text { mean } \\
\text { flow } \\
\text { region } 2 \\
\left(\mathrm{ft}^{3} / \mathrm{s}\right)\end{array}$ & $\begin{array}{c}\text { USGS } \\
\text { site } \\
\text { number }\end{array}$ & USGS station name & $\begin{array}{l}\text { Latitude } \\
\text { (decimal } \\
\text { degrees) }\end{array}$ & $\begin{array}{l}\text { Longitude } \\
\text { (decimal } \\
\text { degrees) }\end{array}$ & $\begin{array}{c}\text { Begin } \\
\text { date }\end{array}$ & $\begin{array}{l}\text { End } \\
\text { date }\end{array}$ & $\begin{array}{l}\text { Period of } \\
\text { record } \\
\text { (years) }\end{array}$ \\
\hline 1 & $\checkmark$ & -- & -- & 07047600 & Tyronza River near Tyronza, Ark. & 35.505082 & -90.380101 & $10 / 01 / 1949$ & $09 / 30 / 1974$ & 25 \\
\hline 2 & $\checkmark$ & -- & -- & 07047942 & L'Anguille River near Colt, Ark. & 35.144722 & -90.878056 & $10 / 01 / 1970$ & $09 / 30 / 2013$ & 33 \\
\hline 3 & $\checkmark$ & -- & -- & 07047950 & L'Anguille River at Palestine, Ark. & 34.972778 & -90.885556 & $10 / 01 / 1949$ & $09 / 30 / 2013$ & 64 \\
\hline 4 & $\checkmark$ & -- & $\checkmark$ & 07048000 & West Fork White River at Greenland, Ark. & 35.982906 & -94.172622 & $10 / 01 / 1945$ & 09/30/1983 & 38 \\
\hline 5 & $\checkmark$ & -- & $\checkmark$ & 07048600 & White River near Fayetteville, Ark. & 36.073056 & -94.081111 & $10 / 01 / 1963$ & $09 / 30 / 2013$ & 50 \\
\hline 6 & $\checkmark$ & -- & $\checkmark$ & 07048800 & Richland Creek at Goshen, Ark. & 36.104167 & -94.007500 & $10 / 01 / 1998$ & $09 / 30 / 2013$ & 15 \\
\hline 7 & $\checkmark$ & -- & $\checkmark$ & 07049000 & War Eagle Creek near Hindsville, Ark. & 36.200000 & -93.855000 & $10 / 01 / 1952$ & $09 / 30 / 2013$ & 61 \\
\hline 8 & $\checkmark$ & -- & $\checkmark$ & 07050000 & White River at Beaver, Ark. & 36.472293 & -93.765472 & $10 / 01 / 1909$ & $09 / 30 / 1958$ & 49 \\
\hline 9 & $\checkmark$ & -- & $\checkmark$ & 07050500 & Kings River near Berryville, Ark. & 36.427222 & -93.620833 & $10 / 01 / 1939$ & $09 / 30 / 2013$ & 74 \\
\hline 10 & $\checkmark$ & -- & $\checkmark$ & 07053207 & Long Creek at Denver, Ark. & 36.389444 & -93.315833 & $10 / 01 / 1996$ & $09 / 30 / 2012$ & 16 \\
\hline 11 & $\checkmark$ & -- & $\checkmark$ & 07053250 & Yocum Creek near Oak Grove, Ark. & 36.454444 & -93.356111 & $10 / 01 / 1993$ & $09 / 30 / 2013$ & 20 \\
\hline 12 & -- & $\checkmark$ & -- & 07053810 & Bull Creek near Walnut Shade, Mo. & 36.717750 & -93.206806 & $10 / 01 / 1997$ & $09 / 30 / 2013$ & 16 \\
\hline 13 & -- & $\checkmark$ & -- & 07054080 & Beaver Creek at Bradleyville, Mo. & 36.779639 & -92.907278 & $10 / 01 / 1994$ & $09 / 30 / 2013$ & 19 \\
\hline 14 & $\checkmark$ & -- & $\checkmark$ & 07055646 & Buffalo River near Boxley, Ark. & 35.938889 & -93.405000 & $10 / 01 / 1993$ & $09 / 30 / 2013$ & 20 \\
\hline 15 & $\checkmark$ & -- & $\checkmark$ & 07055875 & Richland Creek near Witts Spring, Ark. & 35.797222 & -92.928889 & $10 / 01 / 1995$ & $09 / 30 / 2013$ & 18 \\
\hline 16 & $\checkmark$ & -- & $\checkmark$ & 07056000 & Buffalo River near St. Joe, Ark. & 35.983056 & -92.747222 & $10 / 01 / 1939$ & $09 / 30 / 2013$ & 74 \\
\hline 17 & $\checkmark$ & -- & $\checkmark$ & 07056515 & Bear Creek near Silver Hill, Ark. & 35.940000 & -92.713333 & $01 / 22 / 1999$ & $09 / 30 / 2013$ & 14 \\
\hline 18 & $\checkmark$ & -- & $\checkmark$ & 07057000 & Buffalo River near Rush, Ark. & 36.117294 & -92.554607 & $10 / 01 / 1928$ & 09/30/1970 & 42 \\
\hline 19 & -- & $\checkmark$ & -- & 07057500 & North Fork River near Tecumseh, Mo. & 36.623028 & -92.248139 & $10 / 01 / 1944$ & $09 / 30 / 2013$ & 69 \\
\hline 20 & -- & $\checkmark$ & -- & 07058000 & Bryant Creek near Tecumseh, Mo. & 36.627222 & -92.306056 & $10 / 01 / 1944$ & $09 / 30 / 2013$ & 69 \\
\hline 21 & -- & $\checkmark$ & -- & 07058500 & North Fork River at Tecumseh, Mo. & 36.587611 & -92.288856 & $10 / 01 / 1921$ & 09/30/1944 & 23 \\
\hline 22 & $\checkmark$ & $\checkmark$ & -- & 07060710 & North Sylamore Creek near Fifty Six, Ark. & 35.991667 & -92.213889 & $10 / 01 / 1966$ & $09 / 30 / 2013$ & 47 \\
\hline 23 & -- & $\checkmark$ & -- & 07065495 & Jacks Fork at Alley Spring, Mo. & 37.148167 & -91.443083 & $10 / 01 / 1993$ & $09 / 30 / 2013$ & 20 \\
\hline 24 & -- & $\checkmark$ & -- & 07066000 & Jacks Fork at Eminence, Mo. & 37.154083 & -91.358167 & $10 / 01 / 1922$ & $09 / 30 / 2013$ & 91 \\
\hline 25 & -- & $\checkmark$ & -- & 07068000 & Current River at Doniphan, Mo. & 36.622003 & -90.847623 & $10 / 01 / 1921$ & $09 / 30 / 2013$ & 92 \\
\hline 26 & -- & $\checkmark$ & -- & 07068510 & Little Black River below Fairdealing, Mo. & 36.631724 & -90.575393 & $10 / 01 / 1980$ & $09 / 30 / 2013$ & 33 \\
\hline 27 & $\checkmark$ & $\checkmark$ & -- & 07069000 & Black River at Pocahontas, Ark. & 36.254167 & -90.970278 & $10 / 01 / 1980$ & $09 / 30 / 2013$ & 33 \\
\hline 28 & $\checkmark$ & $\checkmark$ & -- & 07069305 & Spring River at Town Branch Bridge at Hardy, Ark. & 36.313611 & -91.482778 & $10 / 01 / 2001$ & $09 / 30 / 2013$ & 12 \\
\hline 29 & $\checkmark$ & $\checkmark$ & -- & 07069500 & Spring River at Imboden, Ark. & 36.205556 & -91.171667 & $10 / 01 / 1936$ & $09 / 30 / 2013$ & 77 \\
\hline 30 & -- & $\checkmark$ & -- & 07070500 & Eleven Point River near Thomasville, Mo. & 36.784780 & -91.492084 & $10 / 01 / 1950$ & 09/30/1976 & 26 \\
\hline
\end{tabular}


Table 1-1. U.S. Geological Survey streamflow gages used for regression analysis for dry season mean monthly flow and harmonic mean flow.-Continued

[ft 3 s, cubic feet per second; USGS, U.S. Geological Survey; Ark., Arkansas; Mo., Missouri; Okla., Oklahoma; --, gage was not used for the regression in the column heading for that station]

\begin{tabular}{|c|c|c|c|c|c|c|c|c|c|c|}
\hline $\begin{array}{c}\text { Map } \\
\text { identi- } \\
\text { fication } \\
\text { number }\end{array}$ & $\begin{array}{c}\text { Dry season } \\
\text { mean } \\
\text { monthly } \\
\text { streamflow } \\
\left(\mathrm{ft}^{3} / \mathrm{s}\right)\end{array}$ & $\begin{array}{l}\text { Harmonic } \\
\text { mean } \\
\text { flow } \\
\text { region } 1 \\
\left(\mathrm{ft}^{3} / \mathrm{s}\right)\end{array}$ & $\begin{array}{c}\text { Harmonic } \\
\text { mean } \\
\text { flow } \\
\text { region } 2 \\
\left(\mathrm{ft}^{3} / \mathrm{s}\right)\end{array}$ & $\begin{array}{c}\text { USGS } \\
\text { site } \\
\text { number }\end{array}$ & USGS station name & $\begin{array}{l}\text { Latitude } \\
\text { (decimal } \\
\text { degrees) }\end{array}$ & $\begin{array}{c}\text { Longitude } \\
\text { (decimal } \\
\text { degrees) }\end{array}$ & $\begin{array}{c}\text { Begin } \\
\text { date }\end{array}$ & $\begin{array}{l}\text { End } \\
\text { date }\end{array}$ & $\begin{array}{c}\text { Period of } \\
\text { record } \\
\text { (years) }\end{array}$ \\
\hline 31 & -- & $\checkmark$ & -- & 07071500 & Eleven Point River near Bardley, Mo. & 36.648694 & -91.200833 & $10 / 01 / 1921$ & $09 / 30 / 2013$ & 92 \\
\hline 32 & $\checkmark$ & $\checkmark$ & -- & 07072000 & Eleven Point River near Ravenden Springs, Ark. & 36.346389 & -91.114167 & $10 / 01 / 1929$ & $09 / 30 / 2013$ & 84 \\
\hline 33 & $\checkmark$ & $\checkmark$ & -- & 07072500 & Black River at Black Rock, Ark. & 36.102500 & -91.097778 & $10 / 01 / 1929$ & $09 / 30 / 2013$ & 84 \\
\hline 34 & $\checkmark$ & $\checkmark$ & -- & 07073000 & Strawberry River near Evening Shade, Ark. & 36.098959 & -91.608474 & $10 / 01 / 1939$ & 09/30/1979 & 40 \\
\hline 35 & $\checkmark$ & $\checkmark$ & -- & 07073500 & Piney Fork at Evening Shade, Ark. & 36.080626 & -91.610974 & $10 / 01 / 1939$ & 09/30/1984 & 45 \\
\hline 36 & $\checkmark$ & $\checkmark$ & -- & 07074000 & Strawberry River near Poughkeepsie, Ark. & 36.111111 & -91.449444 & $10 / 01 / 1936$ & 09/30/1987 & 51 \\
\hline 37 & $\checkmark$ & -- & $\checkmark$ & 07075000 & Middle Fork of Little Red River at Shirley, Ark. & 35.656667 & -92.292778 & $10 / 01 / 1939$ & $09 / 30 / 2013$ & 74 \\
\hline 38 & $\checkmark$ & -- & $\checkmark$ & 07075300 & South Fork of Little Red River at Clinton, Ark. & 35.586944 & -92.451389 & $10 / 01 / 1961$ & 09/30/2012 & 51 \\
\hline 39 & $\checkmark$ & -- & $\checkmark$ & 07075500 & South Fork Little Red River near Clinton, Ark. & 35.566744 & -92.383490 & $10 / 01 / 1939$ & 09/30/1961 & 22 \\
\hline 40 & $\checkmark$ & -- & -- & 07077380 & Cache River at Egypt, Ark. & 35.857500 & -90.933056 & $10 / 01 / 1964$ & $09 / 30 / 2013$ & 49 \\
\hline 41 & $\checkmark$ & -- & -- & 07077500 & Cache River at Patterson, Ark. & 35.269722 & -91.236389 & $10 / 01 / 1927$ & $09 / 30 / 2010$ & 83 \\
\hline 42 & $\checkmark$ & -- & -- & 07077555 & Cache River near Cotton Plant, Ark. & 35.035556 & -91.322500 & $10 / 01 / 1987$ & $09 / 30 / 2013$ & 26 \\
\hline 43 & $\checkmark$ & -- & -- & 07077950 & Big Creek at Poplar Grove, Ark. & 34.555656 & -90.845669 & $10 / 01 / 1970$ & 09/30/1993 & 23 \\
\hline 44 & -- & $\checkmark$ & -- & 07189000 & Elk River near Tiff City, Mo. & 36.631461 & -94.586889 & $10 / 01 / 1939$ & $09 / 30 / 2013$ & 74 \\
\hline 45 & -- & $\checkmark$ & -- & 07189540 & Cave Springs Branch near South West City, Mo. & 36.547297 & -94.618000 & $10 / 01 / 1997$ & $09 / 30 / 2013$ & 16 \\
\hline 46 & -- & $\checkmark$ & -- & 07189542 & Honey Creek near South West City, Mo. & 36.548889 & -94.683611 & $10 / 01 / 1997$ & $09 / 30 / 2013$ & 16 \\
\hline 47 & $\checkmark$ & $\checkmark$ & -- & 07191160 & Spavinaw Creek near Maysville, Ark. & 36.364523 & -94.551330 & $10 / 01 / 2001$ & $09 / 30 / 2013$ & 12 \\
\hline 48 & $\checkmark$ & $\checkmark$ & -- & 07191179 & Spavinaw Creek near Cherokee City, Ark. & 36.342024 & -94.587720 & $10 / 01 / 2001$ & $09 / 30 / 2013$ & 12 \\
\hline 49 & -- & $\checkmark$ & -- & 07191220 & Spavinaw Creek near Sycamore, Okla. & 36.334722 & -94.641389 & $10 / 01 / 1961$ & $09 / 30 / 2013$ & 52 \\
\hline 50 & $\checkmark$ & $\checkmark$ & -- & 07194800 & Illinois River at Savoy, Ark. & 36.103056 & -94.344444 & $10 / 01 / 1979$ & $09 / 30 / 2013$ & 34 \\
\hline 51 & $\checkmark$ & $\checkmark$ & -- & 07195400 & $\begin{array}{l}\text { Illinois River at Highway } 16 \text { near Siloam Springs } \\
\text { Ark. }\end{array}$ & 36.144722 & -94.494722 & $10 / 01 / 1979$ & $09 / 30 / 2013$ & 34 \\
\hline 52 & $\checkmark$ & $\checkmark$ & -- & 07195430 & Illinois River South of Siloam Springs, Ark. & 36.108611 & -94.533333 & $10 / 01 / 1995$ & $09 / 30 / 2013$ & 18 \\
\hline 53 & $\checkmark$ & $\checkmark$ & -- & 07195800 & Flint Creek at Springtown, Ark. & 36.256111 & -94.433611 & $10 / 01 / 1961$ & $09 / 30 / 2013$ & 52 \\
\hline 54 & -- & $\checkmark$ & -- & 07195855 & Flint Creek near West Siloam Springs, Okla. & 36.216111 & -94.605278 & $10 / 01 / 1979$ & $09 / 30 / 2013$ & 34 \\
\hline 55 & $\checkmark$ & $\checkmark$ & -- & 07196900 & Baron Fork at Dutch Mills, Ark. & 35.880000 & -94.486389 & $10 / 01 / 1958$ & $09 / 30 / 2013$ & 55 \\
\hline 56 & -- & $\checkmark$ & -- & 07197360 & Caney Creek near Barber, Okla. & 35.785091 & -94.856340 & $10 / 01 / 1997$ & $09 / 30 / 2013$ & 16 \\
\hline 57 & $\checkmark$ & -- & $\checkmark$ & 07247000 & Poteau River at Cauthron, Ark. & 34.918889 & -94.299444 & $10 / 01 / 1939$ & $09 / 30 / 2013$ & 74 \\
\hline 58 & -- & -- & $\checkmark$ & 07247500 & Fourche Maline near Red Oak, Okla. & 34.912599 & -95.155799 & $10 / 01 / 1938$ & $09 / 30 / 2013$ & 75 \\
\hline 59 & $\checkmark$ & -- & $\checkmark$ & 07249400 & James Fork near Hackett, Ark. & 35.162500 & -94.406944 & $10 / 01 / 1958$ & $09 / 30 / 2013$ & 55 \\
\hline 60 & -- & -- & $\checkmark$ & 07249413 & Poteau River near Pama, Okla. & 35.165653 & -94.653002 & $10 / 01 / 1989$ & $09 / 30 / 2013$ & 24 \\
\hline 61 & $\checkmark$ & -- & $\checkmark$ & 07249500 & Cove Creek near Lee Creek, Ark. & 35.722306 & -94.407992 & $10 / 01 / 1950$ & 09/30/1970 & 20 \\
\hline 62 & -- & -- & $\checkmark$ & 07249985 & Lee Creek near Short, Okla. & 35.517222 & -94.464167 & $10 / 01 / 1930$ & $09 / 30 / 2013$ & 83 \\
\hline
\end{tabular}


Table 1-1. U.S. Geological Survey streamflow gages used for regression analysis for dry season mean monthly flow and harmonic mean flow.-Continued

$\left[\mathrm{ft}^{3} / \mathrm{s}\right.$, cubic feet per second; USGS, U.S. Geological Survey; Ark., Arkansas; Mo., Missouri; Okla., Oklahoma; --, gage was not used for the regression in the column heading for that station]

\begin{tabular}{|c|c|c|c|c|c|c|c|c|c|c|}
\hline $\begin{array}{c}\text { Map } \\
\text { identi- } \\
\text { fication } \\
\text { number }\end{array}$ & $\begin{array}{c}\text { Dry season } \\
\text { mean } \\
\text { monthly } \\
\text { streamflow } \\
\left(\mathrm{ft}^{3} / \mathrm{s}\right)\end{array}$ & $\begin{array}{c}\text { Harmonic } \\
\text { mean } \\
\text { flow } \\
\text { region } 1 \\
\left(\mathrm{ft}^{3} / \mathrm{s}\right)\end{array}$ & $\begin{array}{c}\text { Harmonic } \\
\text { mean } \\
\text { flow } \\
\text { region } 2 \\
\left(\mathrm{ft}^{3} / \mathrm{s}\right)\end{array}$ & $\begin{array}{c}\text { USGS } \\
\text { site } \\
\text { number }\end{array}$ & USGS station name & $\begin{array}{l}\text { Latitude } \\
\text { (decimal } \\
\text { degrees) }\end{array}$ & $\begin{array}{c}\text { Longitude } \\
\text { (decimal } \\
\text { degrees) }\end{array}$ & $\begin{array}{c}\text { Begin } \\
\text { date }\end{array}$ & $\begin{array}{l}\text { End } \\
\text { date }\end{array}$ & $\begin{array}{l}\text { Period of } \\
\text { record } \\
\text { (years) }\end{array}$ \\
\hline 63 & $\checkmark$ & -- & $\checkmark$ & 07250000 & Lee Creek near Van Buren, Ark. & 35.494533 & -94.449659 & $10 / 01 / 1930$ & $09 / 30 / 1992$ & 62 \\
\hline 64 & -- & -- & $\checkmark$ & 07250935 & Jones Creek at Winfrey, Ark. & 35.735833 & -94.103056 & $10 / 01 / 2000$ & $09 / 30 / 2013$ & 13 \\
\hline 65 & $\checkmark$ & -- & $\checkmark$ & 07251000 & Frog Bayou near Mountainburg, Ark. & 35.660361 & -94.149094 & $10 / 01 / 1936$ & 09/30/1961 & 25 \\
\hline 66 & $\checkmark$ & -- & $\checkmark$ & 07252000 & Mulberry River near Mulberry, Ark. & 35.576944 & -94.015278 & $10 / 01 / 1938$ & $09 / 30 / 2013$ & 75 \\
\hline 67 & $\checkmark$ & -- & -- & 07252500 & $\begin{array}{l}\text { Sixmile Creek subwatershed } 6 \text { near Chismville, } \\
\text { Ark. }\end{array}$ & 35.208989 & -93.878247 & $10 / 01 / 1955$ & $09 / 30 / 1970$ & 15 \\
\hline 68 & $\checkmark$ & -- & -- & 07253000 & Sixmile Creek at Chismville, Ark. & 35.220925 & -93.939091 & $10 / 01 / 1954$ & 09/30/1969 & 15 \\
\hline 69 & $\checkmark$ & -- & -- & 07253500 & Sixmile Creek near Branch, Ark. & 35.248703 & -93.974647 & $10 / 01 / 1954$ & 09/30/1969 & 15 \\
\hline 70 & $\checkmark$ & -- & -- & 07255000 & Sixmile Creek at Caulksville, Ark. & 35.301478 & -93.854366 & $10 / 01 / 1954$ & 09/30/1969 & 15 \\
\hline 71 & $\checkmark$ & -- & -- & 07255500 & Hurricane Creek near Branch, Ark. & 35.350572 & -93.934392 & $10 / 01 / 1954$ & 09/30/1969 & 15 \\
\hline 72 & $\checkmark$ & -- & $\checkmark$ & 07256000 & Hurricane Creek near Caulksville, Ark. & 35.346889 & -93.863058 & $10 / 01 / 1954$ & 09/30/1969 & 15 \\
\hline 73 & $\checkmark$ & -- & $\checkmark$ & 07256500 & Spadra Creek at Clarksville, Ark. & 35.468333 & -93.463056 & $10 / 01 / 1952$ & $09 / 30 / 1970$ & 18 \\
\hline 74 & $\checkmark$ & -- & $\checkmark$ & 07257000 & Big Piney Creek near Dover, Ark. & 35.549525 & -93.158508 & $10 / 01 / 1950$ & 09/30/1992 & 42 \\
\hline 75 & $\checkmark$ & -- & $\checkmark$ & 07257006 & Big Piney Creek at Highway 164 near Dover, Ark. & 35.505833 & -93.181389 & $10 / 01 / 1992$ & $09 / 30 / 2013$ & 21 \\
\hline 76 & $\checkmark$ & -- & $\checkmark$ & 07257500 & Illinois Bayou near Scottsville, Ark. & 35.466389 & -93.041111 & $10 / 01 / 1947$ & $09 / 30 / 2013$ & 66 \\
\hline 77 & $\checkmark$ & -- & $\checkmark$ & 07258500 & Petit Jean River near Booneville, Ark. & 35.106944 & -93.923611 & $10 / 01 / 1939$ & $09 / 30 / 2013$ & 74 \\
\hline 78 & $\checkmark$ & -- & $\checkmark$ & 07259500 & Petit Jean River near Waveland, Ark. & 35.104813 & -93.631582 & $10 / 01 / 1939$ & 09/30/1986 & 47 \\
\hline 79 & $\checkmark$ & -- & $\checkmark$ & 07260000 & Dutch Creek at Waltreak, Ark. & 34.986944 & -93.613056 & $10 / 01 / 1945$ & $09 / 30 / 2013$ & 68 \\
\hline 80 & $\checkmark$ & -- & $\checkmark$ & 07260500 & Petit Jean River at Danville, Ark. & 35.058611 & -93.395556 & $10 / 01 / 1916$ & $09 / 30 / 2013$ & 97 \\
\hline 81 & $\checkmark$ & -- & $\checkmark$ & 07261000 & Cadron Creek near Guy, Ark. & 35.298611 & -92.403889 & $10 / 01 / 1954$ & $09 / 30 / 2013$ & 59 \\
\hline 82 & $\checkmark$ & -- & $\checkmark$ & 07261500 & Fourche LaFave River near Gravelly, Ark. & 34.872500 & -93.657222 & $10 / 01 / 1939$ & $09 / 30 / 2013$ & 74 \\
\hline 83 & $\checkmark$ & -- & $\checkmark$ & 07262500 & Fourche LaFave River near Nimrod, Ark. & 34.950646 & -93.154623 & $10 / 01 / 1936$ & 09/30/1980 & 44 \\
\hline 84 & $\checkmark$ & -- & $\checkmark$ & 07263000 & South Fourche LaFave River near Hollis, Ark. & 34.911944 & -93.056111 & $10 / 01 / 1941$ & 09/30/1987 & 46 \\
\hline 85 & $\checkmark$ & -- & $\checkmark$ & 07263295 & Maumelle River at Williams Junction, Ark. & 34.876111 & -92.774444 & $10 / 01 / 1989$ & $09 / 30 / 2013$ & 24 \\
\hline 86 & $\checkmark$ & -- & -- & 07264000 & Bayou Meto near Lonoke, Ark. & 34.736667 & -91.915833 & $10 / 01 / 1954$ & $09 / 30 / 2013$ & 59 \\
\hline 87 & -- & -- & $\checkmark$ & 07337900 & Glover River near Glover, Okla. & 34.097607 & -94.902167 & $10 / 01 / 1961$ & $09 / 30 / 2013$ & 52 \\
\hline 88 & $\checkmark$ & -- & $\checkmark$ & 07339500 & Rolling Fork near DeQueen, Ark. & 34.047500 & -94.412778 & $10 / 01 / 1948$ & 09/30/2011 & 63 \\
\hline 89 & $\checkmark$ & -- & $\checkmark$ & 07340300 & Cossatot River near Vandervoort, Ark. & 34.380000 & -94.236389 & $10 / 01 / 1967$ & $09 / 30 / 2013$ & 46 \\
\hline 90 & $\checkmark$ & -- & $\checkmark$ & 07340500 & Cossatot River near DeQueen, Ark. & 34.045000 & -94.212500 & $10 / 01 / 1948$ & $09 / 30 / 2011$ & 63 \\
\hline 91 & $\checkmark$ & -- & -- & 07341000 & Saline River near Dierks, Ark. & 34.096111 & -94.085000 & $10 / 01 / 1967$ & $09 / 30 / 2013$ & 46 \\
\hline 92 & $\checkmark$ & -- & -- & 07349430 & Bodcau Creek at Stamps, Ark. & 33.366791 & -93.522399 & $10 / 01 / 1938$ & $09 / 30 / 1980$ & 42 \\
\hline 93 & $\checkmark$ & -- & $\checkmark$ & 07356000 & Ouachita River near Mount Ida, Ark. & 34.610000 & -93.697500 & $10 / 01 / 1941$ & $09 / 30 / 2013$ & 72 \\
\hline 94 & $\checkmark$ & -- & $\checkmark$ & 07356500 & South Fork Ouachita River at Mount Ida, Ark. & 34.560375 & -93.636026 & $10 / 01 / 1949$ & 09/30/1970 & 21 \\
\hline
\end{tabular}


Table 1-1. U.S. Geological Survey streamflow gages used for regression analysis for dry season mean monthly flow and harmonic mean flow.-Continued

[ft 3 s, cubic feet per second; USGS, U.S. Geological Survey; Ark., Arkansas; Mo., Missouri; Okla., Oklahoma; --, gage was not used for the regression in the column heading for that station]

\begin{tabular}{|c|c|c|c|c|c|c|c|c|c|c|}
\hline $\begin{array}{l}\text { Map } \\
\text { identi- } \\
\text { fication } \\
\text { number }\end{array}$ & $\begin{array}{c}\text { Dry season } \\
\text { mean } \\
\text { monthly } \\
\text { streamflow } \\
\left(\mathrm{ft}^{3} / \mathrm{s}\right)\end{array}$ & $\begin{array}{c}\text { Harmonic } \\
\text { mean } \\
\text { flow } \\
\text { region } 1 \\
\left(\mathrm{ft}^{3} / \mathrm{s}\right)\end{array}$ & $\begin{array}{c}\text { Harmonic } \\
\text { mean } \\
\text { flow } \\
\text { region } 2 \\
\left(\mathrm{ft}^{3} / \mathrm{s}\right)\end{array}$ & $\begin{array}{c}\text { USGS } \\
\text { site } \\
\text { number }\end{array}$ & USGS station name & $\begin{array}{l}\text { Latitude } \\
\text { (decimal } \\
\text { degrees) }\end{array}$ & $\begin{array}{c}\text { Longitude } \\
\text { (decimal } \\
\text { degrees) }\end{array}$ & $\begin{array}{c}\text { Begin } \\
\text { date }\end{array}$ & $\begin{array}{l}\text { End } \\
\text { date }\end{array}$ & $\begin{array}{c}\text { Period of } \\
\text { record } \\
\text { (years) }\end{array}$ \\
\hline 95 & $\checkmark$ & -- & -- & 07359800 & Caddo River near Alpine, Ark. & 34.266763 & -93.362681 & $10 / 01 / 1938$ & $09 / 30 / 1970$ & 32 \\
\hline 96 & $\checkmark$ & -- & $\checkmark$ & 07360200 & Little Missouri River near Langley, Ark. & 34.311667 & -93.899722 & $10 / 01 / 1998$ & $09 / 30 / 2013$ & 15 \\
\hline 97 & $\checkmark$ & -- & $\checkmark$ & 07360800 & Muddy Fork Creek near Murfreesboro, Ark. & 34.083443 & -93.752128 & $10 / 01 / 1940$ & $09 / 30 / 1959$ & 19 \\
\hline 98 & $\checkmark$ & -- & $\checkmark$ & 07361000 & Little Missouri River near Murfreesboro, Ark. & 34.048721 & -93.720183 & $10 / 01 / 1928$ & 09/30/1977 & 49 \\
\hline 99 & $\checkmark$ & -- & $\checkmark$ & 07361500 & Antoine River at Antoine, Ark. & 34.038889 & -93.418056 & $10 / 01 / 1954$ & $09 / 30 / 2013$ & 59 \\
\hline 100 & $\checkmark$ & -- & $\checkmark$ & 07361600 & Little Missouri River near Boughton, Ark. & 33.878163 & -93.304616 & $10 / 01 / 1937$ & 09/30/1977 & 40 \\
\hline 101 & $\checkmark$ & -- & $\checkmark$ & 07362100 & Smackover Creek near Smackover, Ark. & 33.375278 & -92.776667 & $10 / 01 / 1961$ & $09 / 30 / 2013$ & 52 \\
\hline 102 & $\checkmark$ & -- & $\checkmark$ & 07362500 & Moro Creek near Fordyce, Ark. & 33.792222 & -92.333333 & $10 / 01 / 1951$ & $09 / 30 / 2013$ & 62 \\
\hline 103 & $\checkmark$ & -- & $\checkmark$ & 07362587 & Alum Fork Saline River near Reform, Ark. & 34.797500 & -92.933889 & $10 / 01 / 1989$ & $09 / 30 / 2013$ & 24 \\
\hline 104 & $\checkmark$ & -- & $\checkmark$ & 07363000 & Saline River at Benton, Ark. & 34.567778 & -92.610278 & $10 / 01 / 1950$ & $09 / 30 / 2013$ & 63 \\
\hline 105 & $\checkmark$ & -- & $\checkmark$ & 07363300 & Hurricane Creek near Sheridan, Ark. & 34.319541 & -92.344597 & $10 / 01 / 1961$ & 09/30/1995 & 34 \\
\hline 106 & $\checkmark$ & -- & $\checkmark$ & 07363400 & Hurricane Creek below Sheridan, Ark. & 34.228611 & -92.372500 & $10 / 01 / 2001$ & $09 / 30 / 2013$ & 12 \\
\hline 107 & $\checkmark$ & -- & $\checkmark$ & 07363500 & Saline River near Rye, Ark. & 33.700833 & -92.025833 & $10 / 01 / 1937$ & $09 / 30 / 2013$ & 76 \\
\hline 108 & $\checkmark$ & -- & -- & 07364133 & Bayou Bartholomew at Garrett Bridge, Ark. & 33.866389 & -91.656111 & $10 / 01 / 1987$ & $09 / 30 / 2013$ & 26 \\
\hline 109 & $\checkmark$ & -- & -- & 07364150 & Bayou Bartholomew near McGehee, Ark. & 33.627778 & -91.445833 & $10 / 01 / 1938$ & $09 / 30 / 2013$ & 75 \\
\hline 110 & $\checkmark$ & -- & -- & 07364185 & Bayou Bartholomew near Portland, Ark. & 33.235556 & -91.535556 & $10 / 01 / 1998$ & $09 / 30 / 2013$ & 15 \\
\hline 111 & $\checkmark$ & -- & $\checkmark$ & 07365800 & Cornie Bayou near Three Creeks, Ark. & 33.038056 & -92.940556 & $10 / 01 / 1956$ & 09/30/1987 & 31 \\
\hline 112 & $\checkmark$ & -- & $\checkmark$ & 07365900 & Three Creeks near Three Creeks, Ark. & 33.067082 & -92.884050 & $10 / 01 / 1956$ & 09/30/1971 & 15 \\
\hline 113 & $\checkmark$ & -- & -- & 07369680 & Bayou Macon at Eudora, Ark. & 33.100278 & -91.254444 & $10 / 01 / 1988$ & $09 / 30 / 2013$ & 25 \\
\hline
\end{tabular}




\section{Appendix 2. Definitions of Basin Characteristics Evaluated as Response Variables for Inclusion in the Regression Analysis}

Annual precipitation, in inches, is the average annual precipitation for the drainage basin as computed from PRISM (Prism Climate Group, 2012) data for 1951-2011.

August average precipitation, in inches, is the basin average for the month of August averaged from PRISM (Prism Climate Group, 2012) data for 1981-2010.

Average basin elevation, in feet, is the average elevation of the basin as determined from the National Elevation Dataset (U.S. Geological Survey, 2011) 10 meter grid.

Base flow Index (BFI), dimensionless, is the mean ratio of base flow to annual streamflow from the USGS kriged BFI grid (Falcone and others, 2010) as an averaged value for the basin.

Basin perimeter distance, in miles, is the distance around the boundary of the basin.

Basin shape factor, dimensionless, is the ratio of the total drainage area to the basin length.

Drainage area, in square miles, is the area measured in a horizontal plane that is enclosed by a drainage divide.

Forest, in percent, calculated from the National Land Cover Database as the percentage of the basin that is mixed forested (Jin and others, 2013).

July average precipitation, in inches, as a basin average for the month of July averaged from PRISM (Prism Climate Group, 2012) data for 1981-2010.

Longest flow path length, in miles, is the maximum flow distance within a basin from the start of overland flow to the outlet.

Maximum basin elevation, in feet, is the maximum elevation of the basin computed from the National Elevation Dataset (U.S. Geological Survey, 2011) 10 meter grid.

Mean annual groundwater runoff, in inches, is the portion of the total runoff at the outlet from seepage of water from the ground into a stream channel as computed from geographic information system (GIS) grid from Pugh and Westerman (2014).

Mean annual precipitation 1951-2011, in inches, at the basin outlet is the average annual precipitation as determined from PRISM (Prism Climate Group, 2012) data for 1951-2011.

Mean annual precipitation 1971-2000, in inches, at the basin centroid and averaged for the basin is the average annual precipitation as determined from PRISM (Prism Climate Group, 2012) data for 1971-2000.

Mean annual surface runoff, in inches, is the portion of the total runoff at the outlet that travels over the land surface into the stream channel as computed from GIS grid data from Pugh and Westerman (2014).
Mean annual total runoff, in inches, is the total runoff at the outlet that travels over the land surface and from seepage of water from the ground into the stream channel as computed from GIS grid data from Pugh and Westerman (2014).

Mean dry season groundwater runoff, in inches, is the portion of the total runoff at the outlet from seepage of water from the ground into a stream channel for the months of June through November as computed from GIS grid data from Pugh and Westerman (2014).

Mean dry season precipitation, in inches, is the average precipitation for the months of July through November averaged over the drainage basin as computed from PRISM (Prism Climate Group, 2012) data for 1951-2011.

Mean dry season surface runoff, in inches, is the portion of the total runoff at the outlet that travels over the land surface into the stream channel for the months of June through November as computed from GIS grid data from Pugh and Westerman (2014).

Mean dry season total runoff, in inches, is the total runoff at the outlet that travels over the land surface and from seepage of water from the ground into the stream channel for the months of June through November as computed from GIS grid data from Pugh and Westerman (2014).

Mean wet season groundwater runoff, in inches, is the portion of the total runoff at the outlet from seepage of water from the ground into a stream channel for the months of December through May as computed from GIS grid data from Pugh and Westerman (2014).

Mean wet season precipitation, in inches, is the average precipitation for the months of December through June averaged over the drainage basin as computed from PRISM (Prism Climate Group, 2012) data 1951-2011.

Mean wet season surface runoff, in inches, is the portion of the total runoff at the outlet that travels over the land surface into the stream channel for the months of December through May as computed from GIS grid data from Pugh and Westerman (2014).

Mean wet season total runoff, in inches, is the total runoff at the outlet that travels over the land surface and from seepage of water from the ground into the stream channel for the months of December through May as computed from GIS grid data from Pugh and Westerman (2014).

Minimum basin elevation, in feet, is the maximum elevation of the basin computed from the National Elevation Dataset (U.S. Geological Survey, 2011) 10 meter grid.

November average precipitation, in inches, as a basin average for the month of November averaged from PRISM (Prism Climate Group, 2012) data for 1981-2010. 
October average precipitation, in inches, as a basin average for the month of October averaged from PRISM (Prism Climate Group, 2012) data for 1981-2010.

Outlet elevation, in feet, is the elevation at the gage location computed from the National Elevation Dataset (U.S. Geological Survey, 2011) 10 meter grid.

Percent Cretaceous (K), is the percentage of the basin in which Cretaceous sedimentary rocks dominate the surface of the basin as computed from GIS grid data created by Reed and Bush (2005).

Percent Paleozoic (IPz), is the percentage of the basin in which lower Paleozoic sedimentary rocks dominate the surface of the basin as computed from GIS grid data created by Reed and Bush (2005).

Percent Mississippian, is the percentage of the basin in which Mississippian-age rocks dominate the surface of the basin as computed from GIS grid data from Haley and others (1993).

Percent Middle Paleozoic (mPz), is the percentage of the basin in which Middle Paleozoic sedimentary rocks dominate the surface of the basin as computed from GIS grid data created by Reed and Bush (2005).

Percent Ordovician, is the percentage of the basin in which Ordovician-age rocks dominate the surface of the basin as computed from GIS grid data from Haley and others (1993).

Percent Ordovician and Mississippian, is the percentage of the basin in which Mississippian and Ordovician-age rocks dominate the surface of the basin as computed from GIS grid data from Haley and others (1993).

Percent Paleogene (pgT), is the percentage of the basin in which Paleogene sedimentary rocks dominate the surface of the basin as computed from GIS grid data created by Reed and Bush (2005).

Percent Quaternary (Q), is the percentage of the basin in which Quaternary deposits dominate the surface of the basin as computed from GIS grid data created by Reed and Bush (2005).
Percent Upper Paleozoic (uPz), is the percentage of the basin in which Upper Paleozoic sedimentary rocks dominate the surface of the basin as computed from GIS grid data created by Reed and Bush (2005).

Percent Middle Proterozoic (Yv), is the percentage of the basin in which Middle Proterozoic volcanic rocks dominate the surface of the basin as computed from GIS grid data created by Reed and Bush (2005).

Relief, in feet, is the maximum basin elevation minus the minimum basin elevation computed from the National Elevation Dataset (U.S. Geological Survey, 2011) 10 meter grids.

September average precipitation, in inches, as a basin average for the month of September averaged from PRISM (Prism Climate Group, 2012) data for 1981-2010.

Slope, in feet per mile, of the longest flow path through the basin.

Slope 1085, in feet per mile, is the stream slope computed as the change in elevation between points at 10 and 85 percent of length along the longest flow path from the outlet, determined by GIS, divided by length between the points.

Soil Permeability, in inches per hour, is the rate at which water flows through soil as computed from STATe Soil GeOgraphic (STATSGO) grid data (Schwarz and Alexander, 1995; U.S. Department of Agriculture, 2001).

Soil hydrologic group, dimensionless, percentage of drainage basin in hydrologic soil group as computed from STATe Soil GeOgraphic (STATSGO) grid data (Schwarz and Alexander, 1995; U.S. Department of Agriculture, 2001).

Streamflow-variability Index, dimensionless, is a measure of the steepness of the slope of a streamflow duration curve as computed at the outlet.

Sum of stream lengths for basin, in miles, is the total length of all streams in the basin combined.

Urban, percent, calculated from the National Land Cover Database as the percentage of the basin that is urban (Jin and others, 2013). 


\section{Appendix 3}

Table 3-1. Dry season mean monthly flow, harmonic mean flow, and explanatory variable values for final regression equations.

[USGS, U.S. Geological Survey; $\mathrm{ft}^{3} / \mathrm{s}$, cubic feet per second; Slope1085, slope of channel between points at 10 and 85 percent of the longest flow path from the outlet; mi², square mile; $\mathrm{ft} / \mathrm{mi}^{2}$, foot per mile; in., inches; --, gage was not used for the regression in the column heading for that station; Ark., Arkansas; Mo., Missouri; Okla., Oklahoma]

\begin{tabular}{|c|c|c|c|c|c|c|c|c|c|c|c|c|}
\hline $\begin{array}{c}\text { USGS site } \\
\text { number }\end{array}$ & USGS station name & $\begin{array}{c}\text { Mean } \\
\text { monthly } \\
\text { stream- } \\
\text { flow for } \\
\text { July } \\
\left(\mathrm{ft}^{3} / \mathrm{s}\right)\end{array}$ & $\begin{array}{l}\text { Mean } \\
\text { monthly } \\
\text { stream- } \\
\text { flow for } \\
\text { August } \\
\left(\mathrm{ft}^{3} / \mathrm{s}\right)\end{array}$ & $\begin{array}{c}\text { Mean } \\
\text { monthly } \\
\text { stream- } \\
\text { flow for } \\
\text { Septem- } \\
\text { ber } \\
\left(\mathrm{ft}^{3} / \mathrm{s}\right)\end{array}$ & $\begin{array}{c}\text { Mean } \\
\text { monthly } \\
\text { stream- } \\
\text { flow for } \\
\text { October } \\
\text { (ft's) }\end{array}$ & $\begin{array}{c}\text { Mean } \\
\text { monthly } \\
\text { stream- } \\
\text { flow for } \\
\text { November } \\
\left(\mathrm{ft}^{3} / \mathbf{s}\right)\end{array}$ & $\begin{array}{c}\text { Harmonic } \\
\text { mean } \\
\text { flow } \\
\left(\mathrm{ft}^{3} / \mathbf{s}\right)\end{array}$ & $\begin{array}{l}\text { Base- } \\
\text { flow } \\
\text { index }\end{array}$ & $\begin{array}{c}\text { Drainage } \\
\text { area } \\
\left(\mathrm{mi}^{2}\right)\end{array}$ & $\begin{array}{l}\text { Ordovician } \\
\text { and } \\
\text { Mississip- } \\
\text { pian } \\
\text { (percent) }\end{array}$ & $\begin{array}{c}\text { Slope1085 } \\
\text { (ft/mi) }\end{array}$ & $\begin{array}{l}\text { Mean dry } \\
\text { season } \\
\text { total runoff } \\
\text { (in.) }\end{array}$ \\
\hline 07047600 & Tyronza River near Tyronza, Ark. & 244 & 174 & 165 & 148 & 368 & -- & 0.25 & 332 & 0 & 0.5 & 4.7 \\
\hline 07047942 & L'Anguille River near Colt, Ark. & 265 & 284 & 440 & 332 & 625 & -- & 0.30 & 534 & 0 & 0.7 & 4.8 \\
\hline 07047950 & L'Anguille River at Palestine, Ark. & 412 & 442 & 587 & 374 & 671 & -- & 0.31 & 788 & 0 & 0.7 & 4.8 \\
\hline 07048000 & West Fork White River at Greenland, Ark. & 28 & 26 & 22 & 37 & 100 & 1.44 & 0.30 & 83.0 & 10 & 26.5 & 4.3 \\
\hline 07048600 & White River near Fayetteville, Ark. & 114 & 52 & 148 & 255 & 579 & 11.5 & 0.31 & 399 & 21 & 13.5 & 4.3 \\
\hline 07048800 & Richland Creek at Goshen, Ark. & 69 & 20 & 44 & 55 & 99 & 4.22 & 0.34 & 140 & 28 & 16.6 & 4.3 \\
\hline 07049000 & War Eagle Creek near Hindsville, Ark. & 129 & 68 & 70 & 130 & 199 & 25.0 & 0.33 & 265 & 36 & 8.3 & 4.2 \\
\hline 07050000 & White River at Beaver, Ark. & 660 & 508 & 408 & 649 & 976 & 143 & 0.43 & 1,250 & 48 & 3.9 & 4.3 \\
\hline 07050500 & Kings River near Berryville, Ark. & 213 & 116 & 154 & 209 & 534 & 39.1 & 0.34 & 529 & 70 & 6.2 & 4.3 \\
\hline 07053207 & Long Creek at Denver, Ark. & 37 & 14 & 30 & 95 & 74 & 6.52 & 0.38 & 103 & 79 & 16.5 & 4.3 \\
\hline 07053250 & Yocum Creek near Oak Grove, Ark. & 29 & 21 & 31 & 24 & 45 & 14.4 & 0.36 & 52.6 & 100 & 22.5 & 4.3 \\
\hline 07053810 & Bull Creek near Walnut Shade, Mo. & -- & -- & -- & -- & -- & 11.9 & 0.38 & 196 & 0 & 17.2 & -- \\
\hline 07054080 & Beaver Creek at Bradleyville, Mo. & -- & -- & -- & -- & -- & 69.9 & 0.38 & 298 & 0 & 9.9 & -- \\
\hline 07055646 & Buffalo River near Boxley, Ark. & 14 & 10 & 26 & 38 & 93 & 1.28 & 0.26 & 58.8 & 7 & 40.9 & 4 \\
\hline 07055875 & Richland Creek near Witts Spring, Ark. & 25 & 12 & 31 & 42 & 120 & 1.18 & 0.29 & 67.3 & 1 & 40 & 3.9 \\
\hline 07056000 & Buffalo River near St. Joe, Ark. & 238 & 164 & 226 & 340 & 960 & 118 & 0.34 & 828 & 50 & 9.8 & 4.1 \\
\hline 07056515 & Bear Creek near Silver Hill, Ark. & 26 & 18 & 42 & 38 & 73 & 11.1 & 0.34 & 78.5 & 47 & 36.1 & 4.3 \\
\hline 07057000 & Buffalo River near Rush, Ark. & 405 & 230 & 243 & 354 & 729 & 179 & 0.35 & 1,020 & 58 & 6.8 & 4.3 \\
\hline 07057500 & North Fork River near Tecumseh, Mo. & -- & -- & -- & -- & -- & 484 & 0.58 & 562 & 100 & 7.6 & -- \\
\hline 07058000 & Bryant Creek near Tecumseh, Mo. & -- & -- & -- & -- & -- & 255 & 0.53 & 569 & 100 & 8.2 & -- \\
\hline 07058500 & North Fork River at Tecumseh, Mo. & -- & -- & -- & -- & -- & 752 & 0.50 & 1,160 & 0 & 7.6 & -- \\
\hline 07060710 & North Sylamore Creek near Fifty Six, Ark. & 11 & 10 & 16 & 21 & 47 & 8.82 & 0.33 & 8.4 & 100 & 95.8 & 4.3 \\
\hline 07065495 & Jacks Fork at Alley Spring, Mo. & -- & -- & -- & -- & -- & 101 & 0.47 & 304 & 0 & 10.1 & -- \\
\hline 07066000 & Jacks Fork at Eminence, Mo. & -- & -- & -- & -- & -- & 232 & 0.50 & 404 & 0 & 9.2 & -- \\
\hline 07068000 & Current River at Doniphan, Mo. & -- & -- & -- & -- & -- & 1,920 & 0.55 & 2,050 & 0 & 4.6 & -- \\
\hline 07068510 & Little Black River below Fairdealing, Mo. & -- & -- & -- & -- & -- & 75.4 & 0.51 & 194 & 0 & 8.6 & -- \\
\hline 07069000 & Black River at Pocahontas, Ark. & 3,410 & 2,620 & 2,470 & 2,580 & 3,700 & 3,180 & 0.51 & 4,860 & 66 & 2.3 & 4.2 \\
\hline
\end{tabular}


Table 3-1. Dry season mean monthly flow, harmonic mean flow, and explanatory variable values for final regression equations.-Continued

[USGS, U.S. Geological Survey; $\mathrm{ft}^{3} / \mathrm{s}$, cubic feet per second; Slope1085, slope of channel between points at 10 and 85 percent of the longest flow path from the outlet; mi², square mile; ft/mi, foot per mile; in., inches; --, gage was not used for the regression in the column heading for that station; Ark., Arkansas; Mo., Missouri; Okla., Oklahoma]

\begin{tabular}{|c|c|c|c|c|c|c|c|c|c|c|c|c|}
\hline $\begin{array}{l}\text { USGS site } \\
\text { number }\end{array}$ & USGS station name & $\begin{array}{c}\text { Mean } \\
\text { monthly } \\
\text { stream- } \\
\text { flow for } \\
\text { July } \\
\left(\mathrm{ft}^{3} / \mathrm{s}\right)\end{array}$ & $\begin{array}{c}\text { Mean } \\
\text { monthly } \\
\text { stream- } \\
\text { flow for } \\
\text { August } \\
\left(\mathrm{ft}^{3} / \mathrm{s}\right)\end{array}$ & $\begin{array}{c}\text { Mean } \\
\text { monthly } \\
\text { stream- } \\
\text { flow for } \\
\text { Septem- } \\
\text { ber } \\
\left(\mathrm{ft}^{3} / \mathrm{s}\right)\end{array}$ & $\begin{array}{c}\text { Mean } \\
\text { monthly } \\
\text { stream- } \\
\text { flow for } \\
\text { October } \\
\left(\mathrm{ft}^{3} / \mathrm{s}\right)\end{array}$ & $\begin{array}{c}\text { Mean } \\
\text { monthly } \\
\text { stream- } \\
\text { flow for } \\
\text { November } \\
\left(\mathrm{ft}^{3} / \mathrm{s}\right)\end{array}$ & $\begin{array}{c}\text { Harmonic } \\
\text { mean } \\
\text { flow } \\
\left(\mathrm{ft}^{3} / \mathbf{s}\right)\end{array}$ & $\begin{array}{l}\text { Base- } \\
\text { flow } \\
\text { index }\end{array}$ & $\begin{array}{c}\text { Drainage } \\
\text { area } \\
\left(\mathrm{mi}^{2}\right)\end{array}$ & $\begin{array}{l}\text { Ordovician } \\
\text { and } \\
\text { Mississip- } \\
\text { pian } \\
\text { (percent) }\end{array}$ & $\begin{array}{c}\text { Slope1085 } \\
\text { (ft/mi) }\end{array}$ & $\begin{array}{l}\text { Mean dry } \\
\text { season } \\
\text { total runoff } \\
\quad \text { (in.) }\end{array}$ \\
\hline 07069305 & $\begin{array}{l}\text { Spring River at Town Branch Bridge at Hardy, } \\
\text { Ark. }\end{array}$ & 598 & 500 & 578 & 754 & 814 & 575 & 0.49 & 845 & 100 & 7.5 & 4.7 \\
\hline 07069500 & Spring River at Imboden, Ark. & 766 & 579 & 618 & 686 & 1,170 & 718 & 0.50 & 1,160 & 100 & 6.1 & 4.6 \\
\hline 07070500 & Eleven Point River near Thomasville, Mo. & -- & -- & -- & -- & -- & 19.3 & 0.51 & 358 & 100 & 12.9 & -- \\
\hline 07071500 & Eleven Point River near Bardley, Mo. & -- & -- & -- & -- & -- & 491 & 0.65 & 784 & 100 & 9.7 & -- \\
\hline 07072000 & $\begin{array}{l}\text { Eleven Point River near Ravenden Springs, } \\
\text { Ark. }\end{array}$ & 834 & 685 & 634 & 625 & 875 & 734 & 0.52 & 1,120 & 100 & 7.3 & 4.4 \\
\hline 07072500 & Black River at Black Rock, Ark. & 5,150 & 4,080 & 3,940 & 4,130 & 6,730 & 4,990 & 0.47 & 7,350 & 76 & 2 & 4.5 \\
\hline 07073000 & Strawberry River near Evening Shade, Ark. & 82 & 43 & 61 & 58 & 181 & 32 & 0.47 & 215 & 99 & 5.6 & 4.6 \\
\hline 07073500 & Piney Fork at Evening Shade, Ark. & 29 & 19 & 29 & 27 & 74 & 7.55 & 0.37 & 99.8 & 100 & 7.2 & 4.6 \\
\hline 07074000 & Strawberry River near Poughkeepsie, Ark. & 186 & 123 & 168 & 193 & 407 & 138 & 0.42 & 472 & 100 & 5.7 & 4.6 \\
\hline 07075000 & Middle Fork of Little Red River at Shirley, Ark. & 64 & 83 & 103 & 201 & 423 & 5.21 & 0.28 & 302 & 15 & 13.3 & 4.2 \\
\hline 07075300 & South Fork of Little Red River at Clinton, Ark. & 28 & 19 & 60 & 102 & 242 & 3.05 & 0.28 & 148 & 0 & 18.6 & 4.1 \\
\hline 07075500 & South Fork Little Red River near Clinton, Ark. & 112 & 153 & 90 & 213 & 467 & 2.92 & 0.27 & 317 & 0 & 14.7 & 4.2 \\
\hline 07077380 & Cache River at Egypt, Ark. & 472 & 457 & 490 & 422 & 800 & -- & 0.32 & 691 & 2 & 1 & 4.6 \\
\hline 07077500 & Cache River at Patterson, Ark. & 528 & 448 & 493 & 481 & 911 & -- & 0.29 & 1,030 & 1 & 0.8 & 4.6 \\
\hline 07077555 & Cache River near Cotton Plant, Ark. & 670 & 776 & 633 & 655 & 1,100 & -- & 0.30 & 1,160 & 1 & 0.7 & 4.6 \\
\hline 07077950 & Big Creek at Poplar Grove, Mo. & 150 & 203 & 198 & 186 & 491 & -- & 0.32 & 374 & 0 & 0.7 & 4.9 \\
\hline 07189000 & Elk River near Tiff City, Mo. & -- & -- & -- & -- & -- & 199 & 0.46 & 853 & 100 & 6.8 & -- \\
\hline 07189540 & $\begin{array}{l}\text { Cave Springs Branch near South West City, } \\
\text { Mo. }\end{array}$ & -- & -- & -- & -- & -- & 3.12 & 0.46 & 8.0 & 100 & 27.6 & 4 \\
\hline 07189542 & Honey Creek near South West City, Mo. & -- & -- & -- & -- & -- & 16.0 & 0.46 & 48.7 & 100 & 23.8 & 4 \\
\hline 07191160 & Spaviw Creek near Maysville, Ark. & 53 & 36 & 33 & 43 & 38 & 29.3 & 0.46 & 88.8 & 100 & 18.7 & 4.3 \\
\hline 07191179 & Spaviw Creek near Cherokee City, Ark. & 77 & 33 & 77 & 79 & 164 & 35.4 & 0.46 & 103 & 100 & 16.4 & 4.3 \\
\hline 07191220 & Spaviw Creek near Sycamore, Okla. & -- & -- & -- & -- & -- & 33.1 & 0.48 & 132 & 100 & 14.2 & 3.8 \\
\hline 07194800 & Illinois River at Savoy, Ark. & 77 & 33 & 77 & 79 & 164 & 30.5 & 0.41 & 167 & 74 & 13 & 4.3 \\
\hline 07195400 & $\begin{array}{l}\text { Illinois River at Highway } 16 \text { near Siloam } \\
\text { Springs Ark. }\end{array}$ & 377 & 268 & 386 & 307 & 409 & 258 & 0.43 & 509 & 89 & 7.8 & 4.3 \\
\hline 07195430 & Illinois River South of Siloam Springs, Ark. & 460 & 271 & 350 & 368 & 507 & 282 & 0.43 & 568 & 90 & 7.2 & 4.3 \\
\hline 07195800 & Flint Creek at Springtown, Ark. & 9.7 & 7.5 & 8.5 & 11 & 17 & 6.01 & 0.48 & 14.9 & 100 & 36.4 & 4.3 \\
\hline 07195855 & Flint Creek near West Siloam Springs, Okla. & -- & -- & -- & -- & -- & 14.6 & 0.48 & 56.8 & 0 & 20.5 & 3.8 \\
\hline 07196900 & Baron Fork at Dutch Mills, Ark. & 17 & 7.9 & 21 & 28 & 54 & 2.26 & 0.31 & 41.1 & 58 & 38.4 & 4.2 \\
\hline
\end{tabular}


Table 3-1. Dry season mean monthly flow, harmonic mean flow, and explanatory variable values for final regression equations.-Continued

[USGS, U.S. Geological Survey; $\mathrm{ft}^{3} / \mathrm{s}$, cubic feet per second; Slope1085, slope of channel between points at 10 and 85 percent of the longest flow path from the outlet; mi², square mile; ft/mi, foot per mile; in., inches; --, gage was not used for the regression in the column heading for that station; Ark., Arkansas; Mo., Missouri; Okla., Oklahoma]

\begin{tabular}{|c|c|c|c|c|c|c|c|c|c|c|c|c|}
\hline $\begin{array}{l}\text { USGS site } \\
\text { number }\end{array}$ & USGS station name & $\begin{array}{c}\text { Mean } \\
\text { monthly } \\
\text { stream- } \\
\text { flow for } \\
\text { July } \\
\left(\mathrm{ft}^{3} / \mathrm{s}\right)\end{array}$ & $\begin{array}{c}\text { Mean } \\
\text { monthly } \\
\text { stream- } \\
\text { flow for } \\
\text { August } \\
\left(\mathrm{ft}^{3} / \mathrm{s}\right)\end{array}$ & $\begin{array}{c}\text { Mean } \\
\text { monthly } \\
\text { stream- } \\
\text { flow for } \\
\text { Septem- } \\
\text { ber } \\
\left(\mathrm{ft}^{3} / \mathrm{s}\right)\end{array}$ & $\begin{array}{c}\text { Mean } \\
\text { monthly } \\
\text { stream- } \\
\text { flow for } \\
\text { October } \\
\left(\mathrm{ft}^{3} / \mathrm{s}\right)\end{array}$ & $\begin{array}{c}\text { Mean } \\
\text { monthly } \\
\text { stream- } \\
\text { flow for } \\
\text { November } \\
\left(\mathrm{ft}^{3} / \mathrm{s}\right)\end{array}$ & $\begin{array}{c}\text { Harmonic } \\
\text { mean } \\
\text { flow } \\
\left(\mathrm{ft}^{3} / \mathrm{s}\right)\end{array}$ & $\begin{array}{l}\text { Base- } \\
\text { flow } \\
\text { index }\end{array}$ & $\begin{array}{c}\text { Drainage } \\
\text { area } \\
\left(\mathrm{mi}^{2}\right)\end{array}$ & $\begin{array}{l}\text { Ordovician } \\
\text { and } \\
\text { Mississip- } \\
\text { pian } \\
\text { (percent) }\end{array}$ & $\begin{array}{c}\text { Slope1085 } \\
\text { (ft/mi) }\end{array}$ & $\begin{array}{l}\text { Mean dry } \\
\text { season } \\
\text { total runoff } \\
\text { (in.) }\end{array}$ \\
\hline 07197360 & Caney Creek near Barber, Okla. & -- & -- & -- & -- & -- & 23.8 & 0.38 & 90.2 & 100 & 20.9 & 4.1 \\
\hline 07247000 & Poteau River at Cauthron, Ark. & 61 & 25 & 53 & 112 & 269 & 3.27 & 0.18 & 204 & 0 & 8.8 & 4.6 \\
\hline 07247500 & Fourche Maline near Red Oak, Okla. & -- & -- & -- & -- & -- & 1.17 & 0.14 & 120 & 0 & 14.6 & 4.3 \\
\hline 07249400 & James Fork near Hackett, Ark. & 49 & 11 & 31 & 74 & 149 & 2.55 & 0.20 & 147 & 0 & 16.1 & 4.2 \\
\hline 07249413 & Poteau River near Pama, Okla. & -- & -- & -- & -- & -- & 70.5 & 0.20 & 1,780 & 0 & 2.6 & 4.3 \\
\hline 07249500 & Cove Creek near Lee Creek, Ark. & 22 & 10 & 11 & 13 & 24 & 0.85 & 0.25 & 34.8 & 11 & 32.3 & 4.1 \\
\hline 07249985 & Lee Creek near Short, Okla. & -- & -- & -- & -- & -- & 3.16 & 0.24 & 434 & 0 & 15.6 & 4.5 \\
\hline 07250000 & Lee Creek near Van Buren, Ark. & 127 & 55 & 139 & 250 & 495 & 3.09 & 0.24 & 438 & 6 & 15.1 & 4.1 \\
\hline 07250935 & Jones Creek at Winfrey, Ark. & -- & -- & -- & -- & -- & 0.74 & 0.23 & 20.5 & 0 & 91.3 & 4.1 \\
\hline 07251000 & Frog Bayou near Mountainburg, Ark. & 27 & 15 & 8.1 & 16 & 54 & 5.78 & 0.23 & 75.0 & 0 & 41.5 & 4.1 \\
\hline 07252000 & Mulberry River near Mulberry, Ark. & 125 & 73 & 102 & 190 & 501 & 4.68 & 0.25 & 374 & 0 & 15.4 & 4 \\
\hline 07252500 & $\begin{array}{l}\text { Sixmile Creek subwatershed } 6 \text { near Chismville, } \\
\text { Ark. }\end{array}$ & 1.6 & 0.7 & 0.82 & 0.51 & 3.7 & -- & 0.21 & 4.1 & 0 & 34.2 & 4 \\
\hline 07253000 & Sixmile Creek at Chismville, Ark. & 10 & 3.3 & 3.1 & 3.7 & 14 & -- & 0.20 & 23.8 & 0 & 24.1 & 3.8 \\
\hline 07253500 & Sixmile Creek near Branch, Ark. & 15 & 5.6 & 5.3 & 7.9 & 22 & -- & 0.20 & 36.3 & 0 & 17.5 & 3.8 \\
\hline 07255000 & Sixmile Creek at Caulksville, Ark. & 40 & 14 & 15 & 27 & 64 & -- & 0.19 & 103 & 0 & 11.7 & 3.8 \\
\hline 07255500 & Hurricane Creek near Branch, Ark. & 7.7 & 3.9 & 2.1 & 7.1 & 15 & -- & 0.21 & 17.7 & 0 & 37.8 & 3.9 \\
\hline 07256000 & Hurricane Creek near Caulksville, Ark. & 22 & 9.1 & 6.9 & 24 & 44 & 0.97 & 0.20 & 53.0 & 0 & 20.9 & 3.9 \\
\hline 07256500 & Spadra Creek at Clarksville, Ark. & 21 & 12 & 21 & 27 & 48 & 3.45 & 0.25 & 61.3 & 0 & 48.8 & 3.9 \\
\hline 07257000 & Big Piney Creek near Dover, Ark. & 69 & 40 & 51 & 134 & 393 & 3.97 & 0.27 & 273 & 3 & 16.3 & 3.8 \\
\hline 07257006 & $\begin{array}{l}\text { Big Piney Creek at Highway } 164 \text { near Dover, } \\
\text { Ark. }\end{array}$ & 101 & 57 & 119 & 166 & 422 & 2.28 & 0.25 & 297 & 3 & 15.6 & 3.8 \\
\hline 07257500 & Illinois Bayou near Scottsville, Ark. & 94 & 63 & 89 & 113 & 258 & 2.71 & 0.26 & 242 & 0 & 25.1 & 3.8 \\
\hline 07258500 & Petit Jean River near Booneville, Ark. & 62 & 30 & 57 & 80 & 194 & 1.21 & 0.18 & 241 & 0 & 8.9 & 4.2 \\
\hline 07259500 & Petit Jean River near Waveland, Ark. & 323 & 206 & 122 & 82 & 251 & 10.9 & 0.22 & 516 & 0 & 4 & 4.1 \\
\hline 07260000 & Dutch Creek at Waltreak, Ark. & 26 & 12 & 33 & 28 & 81 & 0.62 & 0.20 & 81.8 & 0 & 18 & 4.4 \\
\hline 07260500 & Petit Jean River at Danville, Ark. & 345 & 211 & 208 & 190 & 495 & 18.9 & 0.27 & 762 & 0 & 2.9 & 4.2 \\
\hline 07261000 & Cadron Creek near Guy, Ark. & 36 & 40 & 66 & 89 & 257 & 1.96 & 0.27 & 172 & 0 & 6.7 & 4.1 \\
\hline 07261500 & Fourche LaFave River near Gravelly, Ark. & 120 & 49 & 130 & 210 & 467 & 1.71 & 0.22 & 410 & 2 & 10.4 & 4.5 \\
\hline 07262500 & Fourche LaFave River near Nimrod, Ark. & 394 & 170 & 184 & 148 & 468 & 10.4 & 0.19 & 684 & 1 & 6 & 4.3 \\
\hline 07263000 & South Fourche LaFave River near Hollis, Ark. & 45 & 37 & 60 & 110 & 219 & 2.51 & 0.19 & 210 & 5 & 10.6 & 4.2 \\
\hline 07263295 & Maumelle River at Williams Junction, Ark. & 6.2 & 4.4 & 27 & 35 & 63 & 0.70 & 0.21 & 115 & 1 & 17.8 & 3.9 \\
\hline
\end{tabular}


[USGS, U.S. Geological Survey; $\mathrm{ft}^{3} / \mathrm{s}$, cubic feet per second; Slope1085, slope of channel between points at 10 and 85 percent of the longest flow path from the outlet; mi², square mile; ft/mi, foot per mile; in., inches; --, gage was not used for the regression in the column heading for that station; Ark., Arkansas; Mo., Missouri; Okla., Oklahoma]

\begin{tabular}{|c|c|c|c|c|c|c|c|c|c|c|c|c|}
\hline $\begin{array}{c}\text { USGS site } \\
\text { number }\end{array}$ & USGS station name & $\begin{array}{c}\text { Mean } \\
\text { monthly } \\
\text { stream- } \\
\text { flow for } \\
\text { July } \\
\left(\mathrm{ft}^{3} / \mathrm{s}\right)\end{array}$ & $\begin{array}{c}\text { Mean } \\
\text { monthly } \\
\text { stream- } \\
\text { flow for } \\
\text { August } \\
\left(\mathrm{ft}^{3} / \mathrm{s}\right)\end{array}$ & $\begin{array}{c}\text { Mean } \\
\text { monthly } \\
\text { stream- } \\
\text { flow for } \\
\text { Septem- } \\
\text { ber } \\
\left(\mathrm{ft}^{3} / \mathrm{s}\right)\end{array}$ & $\begin{array}{c}\text { Mean } \\
\text { monthly } \\
\text { stream- } \\
\text { flow for } \\
\text { October } \\
\text { (ft's) }\end{array}$ & $\begin{array}{c}\text { Mean } \\
\text { monthly } \\
\text { stream- } \\
\text { flow for } \\
\text { November } \\
\left(\mathrm{ft}^{3} / \mathrm{s}\right)\end{array}$ & $\begin{array}{c}\text { Harmonic } \\
\text { mean } \\
\text { flow } \\
\left(\mathrm{ft}^{3} / \mathbf{s}\right)\end{array}$ & $\begin{array}{l}\text { Base- } \\
\text { flow } \\
\text { index }\end{array}$ & $\begin{array}{c}\text { Drainage } \\
\text { area } \\
\left(\mathbf{m i}^{2}\right)\end{array}$ & $\begin{array}{l}\text { Ordovician } \\
\text { and } \\
\text { Mississip- } \\
\text { pian } \\
\text { (percent) }\end{array}$ & $\begin{array}{c}\text { Slope1085 } \\
\text { (ft/mi) }\end{array}$ & $\begin{array}{l}\text { Mean dry } \\
\text { season } \\
\text { total runoff } \\
\quad \text { (in.) }\end{array}$ \\
\hline 07264000 & Bayou Meto near Lonoke, Ark. & 55 & 50 & 81 & 76 & 253 & -- & 0.28 & 207 & 1 & 4.8 & 4.2 \\
\hline 07337900 & Glover River near Glover, Okla. & -- & -- & -- & -- & -- & 3.69 & 0.18 & 320 & 0 & 13.5 & 4.4 \\
\hline 07339500 & Rolling Fork near DeQueen, Ark. & 87 & 56 & 108 & 114 & 256 & 4.71 & 0.18 & 183 & 88 & 17.4 & 5.6 \\
\hline 07340300 & Cossatot River near Vandervoort, Ark. & 80 & 28 & 72 & 123 & 206 & 34.8 & 0.23 & 89.1 & 80 & 26.1 & 5.4 \\
\hline 07340500 & Cossatot River near DeQueen, Ark. & 174 & 125 & 214 & 200 & 493 & 38.5 & 0.21 & 361 & 90 & 15.2 & 5.6 \\
\hline 07341000 & Saline River near Dierks, Ark. & 53 & 22 & 56 & 54 & 162 & -- & 0.21 & 120 & 90 & 20.6 & 5.6 \\
\hline 07349430 & Bodcau Creek at Stamps, Ark. & 78 & 19 & 31 & 50 & 69 & -- & 0.29 & 236 & 69 & 2.5 & 4.5 \\
\hline 07356000 & Ouachita River near Mount Ida, Ark. & 235 & 100 & 243 & 374 & 721 & 81.9 & 0.25 & 414 & 76 & 8.2 & 4.9 \\
\hline 07356500 & South Fork Ouachita River at Mount Ida, Ark. & 38 & 14 & 29 & 28 & 70 & 7.57 & 0.22 & 61.1 & 100 & 14.7 & 4.9 \\
\hline 07359800 & Caddo River near Alpine, Ark. & 159 & 92 & 127 & 146 & 401 & -- & 0.24 & 35.2 & 99 & 5 & 5.1 \\
\hline 07360200 & Little Missouri River near Langley, Ark. & 54 & 38 & 88 & 89 & 133 & 34.0 & 0.22 & 67.9 & 77 & 36 & 5.4 \\
\hline 07360800 & Muddy Fork Creek near Murfreesboro, Ark. & 50 & 12 & 72 & 60 & 133 & 1.88 & 0.19 & 120 & 50 & 15.9 & 5.6 \\
\hline 07361000 & Little Missouri River near Murfreesboro, Ark. & 486 & 453 & 425 & 311 & 460 & 36.6 & 0.21 & 382 & 57 & 16.2 & 5.6 \\
\hline 07361500 & Antoine River at Antoine, Ark. & 90 & 37 & 54 & 118 & 266 & 2.26 & 0.22 & 179 & 44 & 7.5 & 5.2 \\
\hline 07361600 & Little Missouri River near Boughton, Ark. & 652 & 487 & 628 & 489 & 1,180 & 84.7 & 0.23 & 1,070 & 41 & 7.8 & 4.6 \\
\hline 07362100 & Smackover Creek near Smackover, Ark. & 117 & 42 & 85 & 200 & 229 & 9.33 & 0.25 & 539 & 0 & 2.5 & 3.7 \\
\hline 07362500 & Moro Creek near Fordyce, Ark. & 48 & 22 & 55 & 97 & 104 & 1.14 & 0.23 & 241 & 7 & 2.7 & 3.6 \\
\hline 07362587 & Alum Fork Saline River near Reform, Ark. & 3.4 & 4.1 & 25 & 26 & 49 & 0.61 & 0.18 & 26.6 & 23 & 42.1 & 4.2 \\
\hline 07363000 & Saline River at Benton, Ark. & 150 & 130 & 307 & 281 & 677 & 52.1 & 0.23 & 549 & 83 & 10.4 & 4.1 \\
\hline 07363300 & Hurricane Creek near Sheridan, Ark. & 46 & 24 & 34 & 43 & 142 & 5.58 & 0.25 & 204 & 33 & 5.7 & 3.9 \\
\hline 07363400 & Hurricane Creek below Sheridan, Ark. & 58 & 58 & 110 & 270 & 217 & 4.80 & 0.27 & 262 & 25 & 4.7 & 3.9 \\
\hline 07363500 & Saline River near Rye, Ark. & 590 & 308 & 500 & 643 & 1,290 & 165 & 0.31 & 2,090 & 35 & 2.7 & 3.6 \\
\hline 07364133 & Bayou Bartholomew at Garrett Bridge, Ark. & 264 & 159 & 136 & 197 & 296 & -- & 0.35 & 401 & 0 & 0.5 & 3.8 \\
\hline 07364150 & Bayou Bartholomew near McGehee, Ark. & 225 & 169 & 174 & 213 & 369 & -- & 0.42 & 608 & 0 & 0.4 & 4 \\
\hline 07364185 & Bayou Bartholomew near Portland, Ark. & 495 & 281 & 424 & 644 & 682 & -- & 0.32 & 1,140 & 0 & 0.4 & 3.7 \\
\hline 07365800 & Cornie Bayou near Three Creeks, Ark. & 46 & 15 & 40 & 44 & 131 & 2.74 & 0.24 & 180 & 0 & 2.8 & 3.7 \\
\hline 07365900 & Three Creeks near Three Creeks, Ark. & 25 & 7.7 & 11 & 6.9 & 23 & 1.32 & 0.21 & 50.4 & 0 & 4.4 & 3.7 \\
\hline 07369680 & Bayou Macon at Eudora, Ark. & 235 & 136 & 127 & 149 & 141 & -- & 0.35 & 528 & 0 & 0.8 & 3.9 \\
\hline
\end{tabular}


Publishing support provided by Lafayette Publishing Service Center 
